\title{
ARTÍCULOS
}

\section{FUENTES PRIMARIAS PARA EL ESTUDIO DE LAS RENTAS DE PROPIOS Y ARBITRIOS DE LOS MUNICIPIOS INDIANOS.}

\author{
José Luis Caño Ortigosa \\ Universidad de Cádiz \\ joseluis.ortigosa@uca.es
}

Resumen: La administración política, judicial y económica en la América española se vertebró, en última instancia, a partir de los ayuntamientos y sus gobiernos municipales. Representantes de la autoridad del Rey, eran el eslabón más cercano y directo al vasallo de la jerarquía absolutista. Asimismo, los Cabildos eran la primera representación de la población a la que gobernaban, impartían justicia, cobraban impuestos y daban servicios públicos. En ambos sentidos, en sus gestiones encauzadas verticalmente hacia las instituciones superiores, y hacia abajo en la aplicación de las medidas que aquellas les imponían, su capacidad de acción venía condicionada, sobre todo, por los recursos económicos a su disposición. Aparte, las políticas adoptadas de forma autónoma en los municipios también dependían de la economía local, de la autoridad reconocida y de las mercedes recibidas. Todo ello repercutió en las formas de actuar de cada municipio, en sus intereses y, consecuentemente, en las tipologías documentales que aparecen con más frecuencia en cada uno de ellos. La ordenación de esos tipos documentales, el análisis de su aparición y frecuencia, de las mercedes concedidas y las comunicaciones mantenidas nos aportan relevante y novedosa información que, en estudios comparativos, deben ofrecen nuevas respuestas e interrogantes sobre la temática. Interrogantes a los que hay que encontrar nuevos métodos históricos para darles solución.

Palabras clave: Cuentas municipales, Hacienda, Cabildos, Indias, propios y arbitrios.

Tittle: PRIMARY SOURCES FOR THE STUDY OF THE ECONOMICS OF AMERICAN COLONIAL TOWN HALLS.

Abstract: Economical, judicial and political administration in Spanish America was supported, ultimately, by councils and their local governments. On the one hand, as legal representatives of the royal authority, they were the most close and direct link with the vassals of the absolutist hierarchy. On the other hand Cabildos were the first representatives of the population they ruled, they administer justice, collect taxes and give public services. In both ways, managing up for their superior authorities and managing down applying the current legacy, the ability of councils to act was limited, mainly by the lack of economical resources. Moreover, politics autonomously adopted by local governments depended on several factors as the local economy, their recognized authority and the favours received. All these things affected the ways in which the councils acted and to their interests, and consequently to the types of documents they generated which are the ones we can more frequently find nowadays. The order of those documents, the analysis of their appearances and frequencies, just as the study of the given favours and the communications maintained, provide us lots of relevant and

Recibido: 05-08-2020

Aceptado: 08-08-2020

Cómo citar este artículo: CAÑO ORTIGOSA, José Luis. Fuentes primarias para el estudio de las rentas de propios y arbitrios de los municipios indianos. Naveg@mérica. Revista electrónica editada por la Asociación Española de Americanistas [en línea]. 2020, n. 25. Disponible en: $<$ http://revistas.um.es/navegamerica $>$. [Consulta: Fecha de consulta]. ISSN 1989-211X. 
original information that will offer, through comparative studies, new answers and questions on the subject. Questions that will need new historical methods to be solved.

Keywords: Municipal accounts, Finance office, Town Council, Spanish Indias, own and judgement.

\section{Introducción}

Está fuera de toda duda que el estudio de las cuentas municipales es imprescindible para comprender la realidad económica y social de las distintas localidades ${ }^{1}$, así como la verdadera intensidad con la que, en la Edad Moderna y según los lugares, afectaban conceptos actualmente cuestionados como "absolutismo" y "estado". Es decir, a la relación establecida entre el poder central del rey, que dictaba las leyes y obligaba a pagar impuestos, y el poder municipal en manos de unas élites locales que controlaban el tejido productivo, la fiscalidad y la gestión de su cobro ${ }^{2}$. Dicho de otra forma, la convivencia del "Derecho municipal" y del "Derecho vivo"3 o del Derecho Indiano y las Ordenanzas municipales ${ }^{4}$.

Se trata de un debate ya afrontado por la historiografía desde hace al menos dos décadas, en el que ahora no cabe aquí entrar ${ }^{5}$. En cambio, si se hace necesario recordar que la monarquía hispánica, políticamente se organizaba en torno a dos polos institucionales, el Rey y el Reino, y ambos ejercían el poder bajo su jurisdicción. Una división entre Rey-soberanía y Reino-propiedad en la que el gobierno del monarca descansaba sobre el poder económico del reino. Un reino representado, excepcionalmente, en las Cortes a través de las ciudades, 0 sencillamente en éstas directa e independientemente cuando las Cortes no estaban reunidas, que era lo más habitual ${ }^{6}$.

De hecho, en los últimos años se ha venido demostrando la enorme capacidad de influencia de los poderes locales y territoriales sobre sus sociedades, mientras

\footnotetext{
${ }^{1}$ LORENTE TOLEDO, Luis. Los 'propios y arbitrios' municipales. Una opción para el análisis social en la realidad económica del siglo XIX. En: CASTILLO, Santiago. La historia social en España: actualidad y perspectivas: Actas del I Congreso de la Asociación de Historia Social. Zaragoza: Siglo XXI, 1991, pp. 337-344.

${ }^{2}$ BERNARDO ARES, José Manuel de. Prólogo. En: POZAS POVEDA, Lázaro. Ciudades castellanas y Monarquía Hispánica. La aportación municipal al gasto del Estado. Córdoba: Universidad de Córdoba, 2001, p. XXI.

${ }^{3}$ ZORRAQUÍN BECÚ, Ricardo. El sistema de fuentes en el Derecho indiano. Anuario Históricojurídico ecuatoriano. 1980, vol. VI, pp. 3-54; TAU ANZOATEGUI, Víctor. El Derecho municipal del Perú. Apuntes sobre su configuración. En: La Ley en América Hispánica. Buenos Aires: Academia Nacional de la Historia 1992, pp. 313-345.

${ }^{4}$ VALIENTE OTS, Mauricio. El tratamiento de los no-españoles en las ordenanzas municipales indianas. Estudios de historia social y económica de América. 1996, n. 13, pp. 47-51.

5 TAU ANZOÁTEGUI, Víctor, Nuevos horizontes en el estudio histórico del Derecho Indiano. En: INHIDE (XI Congreso del Instituto Internacional de Historia del Derecho Indiano). Buenos Aires, 1997; GARRIGA, Carlos. ¿De qué hablamos cuando hablamos de Derecho Indiano? En: DUVE, Thomas (coord.). Actas del XIX congreso del Instituto Internacional de Historia de Derecho Indiano. Vol. 1. Berlín, 2017, pp. 223-248.

${ }^{6}$ FORTEA PEREZ, José Ignacio. Las ciudades, las Cortes y el problema de representación política en la Castilla Moderna. En: FORTEA PÉREZ, José Ignacio (ed.). Imágenes de la diversidad. El mundo urbano en la Corona de Castilla (s. XVI-XVIII). Santander: Universidad de Cantabria, 1997, pp. 421446.
} 
que los intentos por parte de la Corona para aumentar la suya, desde arriba, quedaba muy limitada, desde abajo, por parte de quienes debían ponerla en práctica $^{7}$. Y es que, al menos por los ejemplos que conocemos hasta ahora, prácticamente nunca se consiguió un equilibrio entre ambos poderes, salvo excepciones como la producida en Guanajuato desde fines del siglo XVII y hasta finales del siglo XVIII ${ }^{8}$. Así, fue constante la lucha entre ambos poderes, cayendo la suerte a uno u otro según los lugares y el momento. Un ejemplo complejo de estas tensiones fue la ciudad de Santiago de Compostela en el siglo XVI, donde no sólo luchaban las élites urbanas locales y el poder regio, sino también el poder señorial y episcopal ${ }^{9}$. Sea como fuere, lo cierto es que en la España de la Modernidad el poder del monarca fue en crecimiento. Ello, según Nader, pudo ser posible, en cierta medida, debido a la protección que, no casualmente, prestó a las oligarquías locales frente al estamento nobiliario, aunque a veces sus intereses particulares fueran distintos, complementarios o, en ocasiones, opuestos ${ }^{10}$.

Precisamente, en el caso del reino de Castilla, cuyo precedente interesa especialmente en nuestro trabajo por razones que no escapan al lector, ese poder del reino lo atesoraban los cabildos de las veintidós ciudades con derecho a representación, lo que acababa influenciando en su capacidad de gestión sobre sus recursos económicos locales ${ }^{11}$. Por tanto, y es aquí donde reside el interés de estas primeras palabras, para comprender el ejercicio gubernativo en su forma más directa y cercana al conjunto de la población debe contemplarse esa doble perspectiva institucional y territorial en sus relaciones verticales y horizontales. Más aún cuando es bien conocido que los ayuntamientos de las colonias presentaron claras características diferenciadoras de los metropolitanos, disfrutando los primeros de unos privilegios, libertades y posibilidades que ya habían desaparecido en la península $^{12}$. Una circunstancia ésta última que Santayana y Bustillo también dejó

\footnotetext{
${ }^{7}$ EMMANUELLI, François Xavier. Un Mythe de l'absolutisme bourbonnien: l'intendance, du milieu du XVIle siecle (France, Spagne, Amerique). Aix en Provenze: Universidad de Provenza, 1981.

${ }^{8}$ CAÑO ORTIGOSA, José Luis. Cabildo y círculos de poder en Guanajuato (1656-1741). Sevilla: Universidad de Sevilla, 2011.

${ }^{9}$ LÓPEZ DÍAZ, María. Señorío y municipalidad. Concurrencia y conflicto de poderes en la ciudad de Santiago (siglos XVI y XVII). Santiago de Compostela: Universidad de Santiago, 1997, pp. 39-41.

${ }_{10}$ NADER, Helen. Liberty in Absolutist Spain. The Habsburg Sale of Towns, 1516-1700. Baltimore: The John Hopkins University Press, 1990.

11 GARCÍA RUIPÉREZ, Mariano. La administración de las haciendas municipales en la Corona de Castilla en el Antiguo Régimen. Estudio archivístico de sus libros registro. En: La scritura de la memoria: Libros para la administración. Actas de las IX Jornadas de la Sociedad Española de Ciencias y Técnicas Historiográficas. Vitoria, 2012, pp. 41-80; Del mismo autor, "Fuentes para el estudio de los precios de los alimentos en los archivos municipales españoles en la Edad Moderna: los libros del juzgado de fieles ejecutores de Toledo. Cuadernos de Historia Moderna. 2017, vol. 42, n. 1, pp. 261-290.

12 REYES OCHOA, Rodolfo. El municipio en la vida americana. México: S.P.I., 1902; SALGADO, José. Los cabildos coloniales. Montevideo, 1910; INGRAM PRIESTLEY, Herbert. Municipalidades coloniales españolas. México: Hermanos Porrúa, 1921; PIERSON, William W. Some reflections on the Cabildo as an institution. Hispanic American Historical Review. 1922, vol. V, n. 4, pp. 573-596; OTS CAPDEQUÍ, José María. El municipio hispanoamericano en la época colonial. Anuario de Historia del Derecho Español. 1924, pp. 93-147; OTS CAPDEQUÍ, José María. El régimen municipal hispanoamericano del período colonial, concejos y ciudades. Tierra Firme. 1937, n. 3 y 4, pp. 353381; OTS CAPDEQUÍ, José María. El Estado español en Indias. México: Fondo de Cultura Económica, 1993; AVELLÁ VIVES, Joaquín. Los cabildos coloniales. Revista de Ciencias Jurídicas y
} 
perfectamente reflejada en 1742 con la intención de asesorar a la nueva Casa reinante, los Borbones, a la hora de implantar el modelo municipal castellano en los territorios de la Corona de Aragón ${ }^{13}$.

De hecho, que todos los ayuntamientos presentaron peculiaridades es una cuestión demostrada, si bien la mayor parte de esas particularidades aún están por descubrirse para la mayoría de los municipios que constituyeron el imperio español. No en vano, en cada lugar, las distintas culturas, el derecho consuetudinario, las costumbres familiares, los valores morales, la estructura socioeconómica y los condicionantes geográfico-paisajísticos configuraron unos determinados poderes locales ${ }^{14}$. Para el caso de la América española, además, se hace especialmente significativa la necesidad de una mayor y mejor investigación, toda vez que ha disfrutado de mucha menos atención que las poblaciones repartidas por los distintos dominios europeos del imperio. Tanto es así que, incluso, Bernardo Ares asevera que el caso del municipalismo americano presenta una mayor complejidad y envergadura que el caso europeo ${ }^{15}$.

Sociales. 1934, vol. 17, n. 67, pp. 343-374; CASARIEGO, Jesús Evaristo. El municipio y las Cortes en el imperio español de Indias. Madrid: Talleres Gráficos Marsiega, 1946; ALTAMIRA Y CREVEA, Rafael. Contribuciones a la Historia Municipal de América. México: Instituto Panamericano de Geografía e Historia, 1951; BAYLE, Constantino. Los cabildos seculares en la América española. Madrid: Sapientia, 1952; ZABALA MANTARAS, Olga. Cabildos coloniales. Montevideo, 1953; ALBI, Fernando. Derecho municipal comparado del mundo hispánico. Madrid: Aguilar, 1955; PIKE, Frederick B. The cabildo and colonial loyalty to Hapsburg Rulers. Journal of Interamerican Studies. 1960, vol. II, n. 4, 1960, pp. 405-420; WOLFF, Inge. Der cabildo im kolonialen Spanisch-Amerika. Jahrbuch für Geschichte von Staat, Wirtschaft und Gesellschaft Lateinamerikas. 1964, vol. I, pp. 365371; TAPIA, Francisco Xavier. El cabildo abierto colonial. Madrid: Cultura Hispánica, 1966; RAMOS PÉREZ, Demetrio. Los cabildos señoriales de la época de Diego Colón. Buenos Aires: Instituto de Investigaciones de Historia del Derecho, 1977; DOMíNGUEZ COMPANY, Francisco. Estudios sobre las instituciones locales hispanoamericanas. Caracas: Academia Nacional de Historia, 1981; MERINO, Luis. El cabildo secular: aspectos fundacionales y administrativos. Estudio sobre el municipio. Manila: Intramuros Administration, 1983; Política de doblamiento de España en América. La fundación de ciudades. Madrid: Instituto de Estudios de Administración Local, 1984; BORAH, Woodrow. El gobierno provincial de la Nueva España 1570-1787. México: UNAM, 1985; SOLANO PÉREZ, Francisco de. Historia y futuro de la ciudad iberoamericana. Madrid: Centro de Estudios Históricos, 1986; MOLINA MARTÍNEZ, Miguel. El municipio en América. Aproximación a su desarrollo histórico. Granada: CEMCI, 1996; KINSBRUNER, Jay. The Colonial Spanish-American City. Urban Life in the Age of Atlantic Capitalism. Austin: University of Texas Press, 2005; LUCENA GIRALDO, Manuel. A los cuatro vientos. Las ciudades de la América Hispánica. Madrid: Fundación Carolina; Centro de Estudios Hispánicos e Iberoamericanos, Marcial Pons, 2006; MARILUZ URQUIJO, José María. El municipio indiano en el siglo XVIII. Revista de Estudios Histórico-Jurídicos. 2006, n. 28, pp. 157-174; CAÑO ORTIGOSA, José Luis. Los cabildos en Indias. Un estudio comparado, Corrientes: Moglia Ediciones, 2009.

${ }^{13}$ SANTAYANA Y BUSTILLO, Lorenzo de. Gobierno político de los pueblos de España y el corregidor, alcalde y juez de ellos. Edición de TOMÁS Y VALIENTE, Francisco. Madrid: Instituto de Estudios de Administración Local, 1979.

${ }^{14}$ ELLIOT, John H. Lengua e Imperio en la España de Felipe IV. Salamanca: Universidad de Salamanca, 1994.

${ }^{15}$ BERNARDO ARES, José Manuel de. El gobierno del Rey y del Reino. La lucha por el poder desde una perspectiva municipal. En: BERNARDO ARES, José Manuel de y GONZÁLEZ BELTRÁN, Jesús Manuel (coords.). La administración municipal en la Edad Moderna. Cádiz: Universidad de Cádiz; Asociación Española de Historia Moderna, 1999, pp. 26-28, 33-34 y 39. 
En efecto, una circunstancia de estudio agravada por la falta de investigaciones que aún se adolece con respecto al conjunto de cabildos indianos ${ }^{16}$, a pesar de que se está evolucionando, aunque sea lentamente, en el conocimiento de esas especificidades locales. Ejemplo de ello es el caso de Jujuy que, a los oficios que nos interesan especialmente, disfrutaba de puestos concejiles como un fiel ejecutor, un procurador general, un mayordomo, un juez tenedor de bienes de difuntos, un alcalde de sacas y hasta alcaldes de aguas, un recurso del que también se conseguían rentas ${ }^{17}$. Y es que, en efecto, en cada lugar cualquier riqueza natural, como el agua de ríos, arroyos, lagos y hasta la nieve de las montañas se asentaban como un patrimonio a explotar entre los propios comunales de las poblaciones, gestionadas por sus responsables políticos. Documentos como la fundación de la ciudad de Salta así lo corroboran, y en sus actas no son escasas las referencias al disfrute y prohibiciones en el uso de ese bien líquido. Unos usos que, en cualquier caso, habían sido establecidos por el Gobernador de Tucumán ${ }^{18}$ y que resultan dignos de mención porque en otros lugares del imperio en las mismas fechas, como el Valle del Cauca al norte del virreinato peruano, la gestión del agua se dividía por distritos fluviales bajo la jurisdicción de un juez para cada uno de ellos ${ }^{19}$.

Aspectos múltiples y muy diversos, como el concreto anterior, que cobran importancia, entonces, cuando se inicia una investigación. $Y$ es que la documentación consultada para cada localidad indiana, en nuestro caso la centrada en la gestión de los recursos municipales, será el producto de su propia particularidad a la hora de beneficiar sus recursos naturales y a la de conformarse, así como de los tipos y maneras de relacionarse con el resto de las instituciones y de los agentes participantes en el devenir del imperio. Todo ello particularizado, además, según el espacio temporal elegido para cada estudio, como se demuestra ya desde la temprana conquista y colonización. El caso de algunas de las primeras poblaciones fundadas en Nueva España, como Colima, son prueba de ello, cuando solicitaron ya en 1525 la posibilidad de tener propios como forma de apaciguar los ánimos de sus pobladores ${ }^{20}$.

Es decir, cada municipio generó en mayor o menor medida unos tipos documentales concretos según fuera su constitución institucional interna, sus prácticas en el ejercicio del poder, los intereses particulares de los responsables de

\footnotetext{
${ }^{16}$ CAÑO ORTIGOSA, José Luis. Los cabildos indianos. Estado de la cuestión, fuentes y archivos para un necesario avance historiográfico. REFA. Revista electrónica de fuentes y archivos. 2019, n. 10, pp. 15-37.

${ }^{17}$ BALDIVIEZO, Dionila. El Cabildo de Jujuy, entre el Antiguo Régimen y la República. En: XII Jornadas Interescuelas. Bariloche: Universidad Nacional del Comahue, 2009, pp. 4-5; Estructura del Cabildo de Jujuy, 1594-1600 [Trabajo de Curso de Postgrado]. Los Cabildos seculares indianos. Una comparativa del poder local en la América española. Universidad Nacional de Salta, julio de 2019, inédito; VERGARA, Miguel Ángel. Orígenes de Jujuy (1535-1600). Salta: Talleres Gráficos "San Martín", 1961.

${ }^{18}$ Extracto de las preeminencias con que fue fundada la ciudad, 1784. Archivo y Biblioteca Históricos de Salta, Actas Capitulares, Carpetas 9 y 15, fols. 23 y 39v, respectivamente.

${ }^{19}$ Informe del Gobernador de Popayán Don Antonio Nieto, 5 de diciembre de 1797, dando cuenta de su Visita a la Provincia, remitido por el Virrey de Santa Fe, Carta núm. 72, de 19 de mayo de 1798. AGI, Santa Fe, 623.

${ }^{20}$ ROMERO DE SOLíS, José Miguel. Conquistas e instituciones de gobierno en Colima de la Nueva España (1523-1600). México: El Colegio de Michoacán, 2007, p. 310.
} 
cada una de las competencias asignadas y las posibilidades y características de los bienes y derechos a explotar. En este sentido, cabe decir entonces que en este trabajo nos ceñiremos a una explicación que se limita exclusivamente a los cabildos indianos bajo dominio español entre los siglos XVI y XVIII, no entrando en particularidades de los ayuntamientos metropolitanos ${ }^{21}$, como tampoco en las propias singularidades surgidas a raíz del reformismo borbónico a final del período colonial. Las razones para ello, entendemos, son de peso, primero por las características propias bien definidas tanto de los concejos peninsulares como de los indianos a partir de la aplicación de aquellas reformas y, segundo, por haber sido tratados ambos aspectos ya en otros trabajos por otros muchos autores ${ }^{22}$. Eso sí,

${ }^{21}$ Para el caso de algunos ayuntamientos peninsulares véase: NÚÑEZ ROLDÁN, Francisco. Haciendas municipales en el Reino de Sevilla a mediados del siglo XVIII. Historia. Instituciones. Documentos. 1985, n. 12, pp. 89-90; GUILLAMÓN, Francisco Javier y PÉREZ HERVÁS, J. Aproximación al estudio de las haciendas locales bajo Carlos III: Los propios del concejo murciano. Revista de la Facultad de Geografía e Historia. 1989, n. 4, pp. 341-356; MARTíNEZ NEIRA, Manuel. El municipio controlado. Los reglamentos de propios y arbitrios en las reformas carolinas. América Latina en la Historia Económica. 1997, vol. 4, n. 7, pp. 9-17; AGÜERO DÍEZ, María Teresa. EI municipio alicantino como agente fiscal de la corona: el equivalente (1759-1788). En: FERNANDEZ ALBADALEJO, Pablo (ed.). Monarquía, Imperio y Pueblos en la España Moderna. Alicante: Universidad de Alicante, 1997, pp. 169-177; GUILLOTO, Fernando. Mayordomos de Propios y Arbitrios de la ciudad de Cádiz en el siglo XVIII. Ateneo: Revista cultural del Ateneo de Cádiz. 2009, n. 9, pp. 184-187; RUBÍN CÓRDOBA, Fernando. La intervención del Asistente e Intendente de Sevilla en la administración de las rentas municipales y provinciales. En: XV Congreso AECA [en línea]. Valladolid, septiembre $\quad 2009 . \quad$ de 2 Disponible $<$ http://www.aeca1.org/pub/on line/comunicaciones xvcongresoaeca/cd/60e.pdf $>$; $\quad P E Z Z I$ CRISTÓBAL, Pilar. Intervencionismo regio en los Cabildos Municipales del Setecientos: el caso de Vélez-Málaga. En: Seminário monarquias ibéricas e elites locais no período moderno [en línea]. Universidade de Lisboa, Faculdade de Letras, 6 Outubro 2015. Disponible en $<$ https://riuma.uma.es/xmlui/handle/10630/10515>; PEZZI CRISTÓBAL, Pilar y VILLAS TINOCO, Siro. Poder y contrapoder: las reformas municipales de Carlos III en Andalucía Oriental. En: ALVAR, Alfredo [et al.]. Política y cultura en la Edad Moderna. Madrid: Universidad de Alcalá, 2004, pp. 803-809; HERNANDO SERRA, María Pilar. Un siglo de reformas: Haciendas municipales y reglamentos en la Valencia del XVIII. Anuario de Historia del Derecho Español. 2013, n. LXXXIII, pp. 543-568; Aparte también podría consultarse la profusa documentación existente al respecto, como las Ordenanzas de la muy noble villa de Bilbao. Bilbao: Francisco de San Martín, 1797; o los papeles conservados en el Archivo Municipal de Burgos, por citar sólo dos ejemplos: Cartas a la ciudad sobre asuntos de propios, 1761, AMB, C2-10-8-11; Reglamentos del Consejo de Propios y Arbitrios de la ciudad (1763 y 1769), 1763-1769, AMB, C-3-13, HI-3126 y C-27-B-22.

22 Para el caso de las reformas en América véase: MURO OREJÓN, Antonio. Reformas e innovaciones en los municipios hispano-indianos en el siglo XVIII. En: Actas VI Congreso Internacional de Historia de América. Tomo III. Buenos Aires: Academia Nacional de la Historia, 1982, pp. 259-275; BER BERNAL RUIZ, Graciela. Poder local y poder político en el transito del antiguo régimen al estado-nación. San Luis Potosí 1786-1826 [tesis doctoral]. Castellón: Universidad Jaume I, 2009; HERRERA MENA, Sajid. El ejercicio de gobernar. Del cabildo borbónico al ayuntamiento liberal. El Salvador colonial, 1750-1821. Castellón: Universidad Jaume I, 2013; MACHUCA, Laura (coord.). Ayuntamientos y sociedad en el tránsito de la época colonial al siglo XIX. Nueva España y Centroamérica. México: CIESAS, 2014; CELAYA NÁNDEZ, Yovana. Las finanzas de las ciudades novohispanas ante el reformismo borbónico: una propuesta historiográfica. En: DUBET, Anne y SOLBES FERRI, Sergio (coords.). La construcción de la Hacienda hispánica en el largo siglo XVIII. Madrid: Casa Velázquez, 2016, pp. 89-97; De la misma autora: Administrar y gobernar la hacienda local: contaduría, intendentes y regidores en el siglo XVIII. En: CELAYA NÁNDEZ, Yovana y SÁNCHEZ SANTIRÓ, Ernest (coords.). Hacienda e instituciones. Los erarios regio, eclesiástico y municipal en Nueva España: coexistencia e interpelaciones. México: Instituto Mora, 2018, pp. 259292; De la misma autora: El Ayuntamiento y el Intendente en San Luis Potosí: conflictos y negociación en la administración de los propios y arbitrios, 1768-1790. Tiempos Modernos. 2016, vol. 33, n. 2, pp. 
haremos algunas referencias precisas a los ayuntamientos imperiales situados en territorios europeos cuando sirvan como precedentes, como elementos de comparación o como ejemplos de producción y gestión de tipos de documentación como la que aquí importa.

Para entender lo difícil de explicar que resultan en este trabajo las peculiaridades propias de la documentación generada por la administración de las cuentas municipales al final de la colonia, a partir de la implantación práctica de algunas de las denominadas reformas borbónicas, utilizaremos el ejemplo de algunas de esas novedades impuestas en la contabilidad municipal de Guanajuato, por ser mejor conocidas para nosotros. Y es que no se trataba sólo de reformar al modo de la nueva dinastía, sino también de dar respuesta a la mayor complejidad que con el paso del tiempo iba adquiriendo la gestión de las rentas locales, un fenómeno lógico al calor del desarrollo que estaban experimentando muchas de las poblaciones indianas. Otro ejemplo precursor de dicha realidad fue la misma capital, Madrid, donde ya a mediados del siglo XVIII se multiplicaban las contadurías para gestionar la hacienda de la ciudad ${ }^{23}$.

Por esa razón, se observa que, especialmente desde la sexta década del siglo XVIII, empiezan a dictarse distintas cédulas y pragmáticas destinadas a mejorar el ordenamiento y gobierno de los propios y arbitrios de las localidades del imperio. De éstas, sólo por citar algunas más significativas, podríamos señalar las Reales Cedulas, Pragmáticas y Órdenes que, entre 1760 y 1793, dieron origen a la

374-398; BERTRAND, Michel y MOUTOUKIAS, Zacarías (coords.). Cambio institucional y fiscalidad. Mundo hispánico, 1760-1850. Madrid: Casa Velázquez, 2018; GARCÍA GARCíA, Carmen. Haciendas municipales y bienes de propios: las reformas de Carlos III. Anales de estudios económicos y empresariales. 1986, n. 1, pp. 89-114; de la misma autora: El reformismo borbónico y la fiscalidad local. Quaderni fiorentini per la storia del pensiero giuridico moderno. 1997, vol. 26, n. 1, pp. 55-84; GARCÍA PÉREZ, Rafael. La implantación de las intendencias americanas. reforma y contrarreforma de los propios y arbitrios. En: TORRES AGUILAR, Manuel (coord.). Actas del XV Congreso del Instituto Internacional de Historia del Derecho Indiano. Vol. 2. Córdoba: Diputación Provincial, 2008, pp. 1641-1662; BUSTAMANTE LÓPEZ, Carlos. Los propios y bienes de comunidad en la provincia de Tlaxcala durante la aplicación de las Reformas Borbónicas, 1787-1804. Estudios de historia novohispana. 2010, n. 43, pp. 145-181; PAYNE IGLESIAS, Elizeth. Poderes locales y resistencia popular en Nicaragua, 1808-1813. En: POLLACK, Aaron. La época de las independencias en Centroamérica y Chiapas. México: Instituto Mora, 2013, pp. 123-158; SILVA RIQUER, Jorge. La reforma fiscal de los ayuntamientos novohispanos (1765-1812). Madrid: Marcial Pons, 2015; GALARZA, Antonio Facundo. Recaudación fiscal, abasto y control del ganado en el Buenos Aires tardocolonial: los propios y arbitrios del Cabildo entre 1780 y 1820. América Latina en la Historia Económica. 2017, vol. 24, n. 2, pp. 7-34; TANCK DE ESTRADA, Dorothy. Pueblos de indios y educación en el México colonial, 1750-1821. México: El Colegio de México, 1999, pp. 17-75; PARRILLA ALBUERNE, Ana María. Propios y arbitrios del ayuntamiento de Ciudad Real. Un pulso entre el poder local y los nuevos funcionarios de la intendencia, 1786-1812. En: ORTIZ HERRERA, María del Rocío (coord.). Ayuntamientos chiapanecos: fiscalidad, elecciones, ciudadanía y defensa de bienes de comunidad desde la Colonia hasta el inicio de la Revolución en Chiapas. México: El Colegio de Michoacán, 2018, pp. 17-48; ABBATE, Georgina. Trayectoria del cabildo en territorios insurgentes. Experiencias políticas en el Río de la Plata (Tucumán, 1809-1824). Temas de historia argentina y americana. 2018, vol. XXVI, pp. 11-38; MARCHIONNI, Marcelo Daniel. Política y sociedad en Salta y el norte argentino, 1780-1850. Salta: ICSOH/UEUCASA, 2019.

${ }^{23}$ SALAMANCA LÓPEZ, Manuel Joaquín. Organización de la Hacienda madrileña durante el reinado de Fernando VI: las contadurías. Cuadernos de investigación histórica. 2015, n. 32, pp. 89-120. 
Contaduría General de Propios y Arbitrios del Reino ${ }^{24}$. También sirvieron para fijar el destino de los sobrantes de esos caudales en cada localidad y para no pagar con los ingresos de los ayuntamientos los costes de las visitas e inspecciones eclesiásticas. Asimismo, se regló el posible interés de los ayuntamientos en suscribir acciones del Banco Nacional con sus sobrantes y se obligó a un único remate en subasta pública de las rentas municipales. No obstante, es necesario recordar que en 1767 se hacía necesario que el Contador General de Propios y Arbitrios dictara otra pragmática debido a la escasa observancia de muchos de los ayuntamientos del imperio ${ }^{25}$.

De este modo, en los años setenta del siglo ilustrado, Gálvez decidió reformar el sistema de administración de los propios de Guanajuato, así como el modo de elaborar y registrar las cuentas que se venía utilizando desde 1732. En 1770 el visitador redactó un formulario para llevar la cuenta general de las rentas consistoriales, dividiéndolas en tres ramos. En esos apartados se incluían los impuestos a los granos y su almacenaje en la alhóndiga municipal, el importe de las licencias de los puestos de las calles, el suelo municipal que se vendía para hacer nuevas casas, los sobrantes de los festejos, las corridas de toros anuales, los impuestos a los vinos y aguardientes, los nuevos impuestos creados para el mantenimiento de las milicias y la creación de infraestructuras de comunicaciones en la ciudad. Para todo ello, a partir de ese momento el procurador debía llevar 17 libros de cuentas, cuatro para los fieles de la alhóndiga y el de entradas del poblado de Marfil y los restantes para las "alhondiguillas" de los barrios y las minas. Uno de esos libros debía ser específico para los impuestos al alcohol y en él debía participar el contador de la aduana, mientras que en otro debían aparecer los gastos de los empedrados de las calles, reparaciones y obras. Los toros, los puestos en alquiler en la calle y la limpieza anual del río no necesitaban de libros específicos, pues se remataban anualmente al mejor postor, necesitando sólo anotar la partida de ingreso de dichas pujas. Otro de los libros debía reflejar el salario de los capitulares y de los trabajadores del ayuntamiento, en el orden especificado por el visitador. Finalmente, después de indicar al procurador general que debía primar el pago de los censos contraídos por el ayuntamiento y la finalización de los préstamos sobre cualquier otro tipo de gastos, se estipulaba un estipendio a favor del capitular del $2 \%$ del total de la cantidad sumada cada año en concepto de ingresos ${ }^{26}$. Años más tarde el virrey continuaría esta misma política impulsada por Gálvez, exigiendo al procurador general de Guanajuato que llevara las cuentas exactas de cada uno de los gastos extraordinarios realizados por el ayuntamiento, aunque el motivo del mismo fuera responsabilidad de otro regidor. Esto fue, por ejemplo, lo que acaeció en 1783, tras

\footnotetext{
${ }^{24}$ RUBÍN CÓRDOBA, Fernando. La Institución de la Contaduría General y Propios y Arbitrios del Reino: organización y normalización de las cuentas (1760-1764). En: VII Encuentro de Trabajo Historia de la Contabilidad [en línea]. León, 12 de noviembre de 2010. Disponible en $<$ https://www.aeca.es/old/vii encuentro trabajo historia contabilidad/pdf/13 Rubin Cordoba.pdf>.

${ }^{25}$ Real Cédula, Madrid, 19 de agosto de 1760; Real Decreto, Madrid 12 de mayo de 1762; Real Orden, Madrid 28 de noviembre de 1763; Real Pragmática, Sevilla, 8 de octubre de 1767; Real Cédula, Madrid, 31 de octubre de 1771; Real Cédula, Madrid, 4 de julio de 1780; Real Cédula, San Ildefonso, 27 de agosto de 1782; Real Cédula, Aranjuez, 1 de mayo de 1793. Madrid: Imprenta de la Viuda e Hijo de Marín, 1793. Disponible en $<$ http://www.bde.es/bde/es/secciones/servicios/Profesionales/Biblioteca/Biblioteca.html>.

${ }^{26}$ Formulario de la cuenta general que debe llevar cada año el procurador general de Guanajuato, 31 de diciembre de 1770. AGN, Ayuntamientos, 134, exp. 5.
} 
la obtención de la licencia del virrey para llevar a cabo una costosa limpieza del río. La dirección y administración de la obra fue designada a un regidor, pero el virrey ordenó la intervención formal del procurador para tener constancia exacta de cada partida al momento de presupuestarla y al de costearla ${ }^{27}$. Un ordenamiento de las finanzas locales que el visitador recomendó en su informe final sobre la reforma de la Hacienda para la práctica totalidad de las poblaciones novohispanas, creando un reglamento que debían acatar los ayuntamientos y añadiendo la instauración de una Contaduría específica de propios y arbitrios. Unas reformas que, sabemos, también fueron aplicadas en otras ciudades como Orizaba, Querétaro y Puebla, creando nuevas instituciones de contabilidad superiores a los ayuntamientos que ya de por sí generaban sus propios conflictos ${ }^{28}$.

Por consiguiente, dependiendo del momento histórico elegido y del tipo de fuentes que se encuentren en cada caso, o según primemos la utilización de unas $u$ otras en nuestras investigaciones, los resultados pueden ser distintos e incluso llegar a ser contradictorios. Tanto es así que utilizar exclusivamente documentos generados en los propios municipios nos puede llevar a una visión municipalista y localista, de la misma forma que emplear únicamente los generados desde las instituciones superiores o paralelas del Estado nos ofrecería otra perspectiva completamente distinta ${ }^{29}$. Sin duda alguna, ambos tipos de fuentes se complementan y nunca deben presentarse como esclarecedoras por separado. Para un buen estudio de las haciendas municipales indianas, las fuentes a consultar deben ser lo más diversas posibles y su análisis el más crítico, relativizando cada información y contrastándola con el resto de las obtenidas. En definitiva, creemos que, si no se describe la realidad económica local a partir de las fuentes municipales, y éstas a su vez se analizan junto a otras de carácter imperial, no podrá llegarse a comprender en profundidad todas sus particularidades ${ }^{30}$.

Consecuentemente, al ser las ciudades y sus instituciones en la práctica las únicas valedoras y ejecutoras del poder real en una parte importante de los territorios colonizados por España, fueron ellas las que, en gran medida, asumieron la administración y la gestión tributaria, tanto del cobro de numerosos y distintos tipos de impuestos como en el gasto de las cantidades obtenidas. Sea como fuere, no todos los investigadores que lean estas líneas deben esperar que sistemáticamente se cumpla la afirmación anterior buscando documentación sobre rentas municipales, gestión de impuestos a nivel local o cualquier otro extremo por

\footnotetext{
${ }^{27}$ Respuesta del virrey a la consulta del cabildo de Guanajuato, México, 27 de febrero de 1783. AGN, Ayuntamientos, 134, exp. 5.

${ }^{28}$ BERTRAND, Michel. Endeudamiento y poder municipal al fin del periodo colonial: el caso de Puebla y CELAYA NÄNDEZ, Yovana. La reforma borbónica en la construcción de la fiscalidad local. Los ayuntamientos novohispanos de Orizaba y Querétaro, ambos en BERTRAND, Michel y MOUTOUKIAS, Zacarías. Cambio institucional y fiscalidad. Mundo hispánico, 1760-1850. Madrid: Casa Velázquez, 2018, pp. 141-156 y 157-173, respectivamente; SUÁREZ GRIMÓN, Vicente J. La reforma de la hacienda municipal en Canarias en el siglo XVIII: el conflicto en torno al establecimiento de la contaduría de propios y arbitrios. Las Palmas de Gran Canaria: Cabildo de Gran Canaria, 2005. ${ }^{29}$ CAÑO ORTIGOSA, José Luis. El Cabildo de Guanajuato y sus relaciones institucionales (16601800). Sevilla: Padilla Libros, 2011; Del mismo autor: Las fuentes judiciales para el estudio de los cabildos indianos. Temas Americanistas. 2019, n. 42, pp. 192-213.

${ }^{30}$ ESPANHA, Antonio M. Vísperas del Leviatán Instituciones y poder político, Portugal, siglo XVII. Madrid: Taurus Humanidades, 1989, pp. 41-42.
} 
parte de los concejos, ya que en algunos lugares los cabildos no fueron más que instituciones testimoniales 0 , de facto, inexistentes ante la presencia de otra autoridad o figura gubernativa. Es el caso acaecido en Tabasco durante gran parte del período colonial, donde no fueron los cabildos, sino los alcaldes mayores, lo que asumieron gran parte de las competencias, incluyendo las económicas y fiscales ${ }^{31}$.

En este aspecto, la Corona y los municipios se complementaban, aunque no olvidaran sus tensiones a la hora de conseguir la mayor parte posible de los montantes recaudados. Es decir, una estrecha relación que no excluía el conflicto, pero sí incluía el pacto, como se ha demostrado para el caso de Burgos a lo largo del siglo $\mathrm{XVI}^{32}$. De hecho, las cantidades recaudadas estaban destinadas a ser una parte importante de las disponibles para que la Corona pudiera hacer frente a sus ingentes necesidades presupuestarias, por lo que las numerosas poblaciones indianas, necesariamente, también debieron representar un porcentaje importante de las aportaciones municipales al erario real. Obviamente, lo anterior no significa que estas mismas localidades no tuvieran sus propias necesidades económicas para su mantenimiento, crecimiento y progreso, todo lo cual salía, generalmente, de las mismas cargas impositivas. El equilibrio, o desequilibrio, manifestado en esas cuentas es clave para entender la gestión del dinero a nivel municipal, y ya en la época no faltaba quien abogaba por la proporcionalidad y la moderación entre los dos poderes, central y local, a la hora de distribuir el gasto público. Así lo expresaba, por ejemplo, el humanista Pérez de Mesa en el siglo $\mathrm{XVI}^{33}$. Sea como fuere, unas cuentas globales de recaudación y de gasto en los municipios que aún esperan ser estudiadas en profundidad para el caso particular de la mayor parte de las poblaciones indianas en su conjunto.

En ese sentido, sirva como un posible modelo de exposición de datos y precursor de análisis para las cuentas municipales de un cabildo indiano el llevado a cabo por Ensinck para el de Buenos Aires. Un modelo sistemático y ordenado en función de la misma presentación que ofrecen los documentos originales consultados, que creemos más funcional y ajustado a la realidad de cada municipio que el intento de crear métodos o clasificaciones metodológicas de carácter general que difícilmente se ajustan a esas diversas y numerosas particularidades ${ }^{34}$.

\footnotetext{
${ }^{31}$ MORENO AMADOR, Carlos. Gobernar bajo sospecha. Estrategias del poder y prácticas corruptas en la Alcaldía Mayor de Tabasco (1660-1716). Sevilla: Universidad de Sevilla, 2018, pp. 113-137 y 184-196.

${ }^{32}$ MATHERS, Constance Jones. Relations between the City of Burgos and the Crown, 1506-1556. Columbia University, 1973; GUTIÉRREZ ALONSO, Adriano y MÉNDEZ SÁEZ, Pablo. La hacienda municipal de Burgos en la época moderna. Los bienes de propios (1500-1750). Boletín de la Institución Fernán González. 1997, n. 215, pp. 327-354.

${ }^{33}$ PÉREZ DE MESA, Diego. Política o Razón de Estado. Edición crítica de PEREFLA, Luciano [et al.]. Madrid: CSIC, 1980, pp. 262-266; ABRIL CASTELLÓ, Vidal. Razón de Estado y política de centro: Diego Pérez de Mesa inventor del "Estado Mesocrático" en la crisis del barroco. Persona y derecho: Revista de fundamentación de las Instituciones Jurídicas y de Derechos Humanos. 1986, n. 15, p. 238.

${ }^{34}$ ENSINCK, Óscar Luis. Propios y arbitrios del Cabildo de Buenos Aires, 1580-1821 (Historia económica de una gran ciudad). Madrid: Instituto de Estudios Fiscales, 1990.
} 


\section{Fuentes primarias básicas}

Se hace necesario comenzar este apartado señalando que no abundaremos en la explicación general de las fuentes que se hacen necesarias para el estudio de los cabildos indianos, ya que ese extremo ha sido expuesto en trabajos anteriores y existen magníficos ejemplos de su utilización para entender las cuentas de una localidad indiana en unas fechas concretas ${ }^{35}$. Sirva aquí a modo de síntesis que, sencillamente, se ha demostrado que la única utilización de las fuentes primarias que se consideraron clásicas durante mucho tiempo para estas investigaciones no son suficientes para obtener unos resultados óptimos y clarificadores. Es decir, Actas Capitulares $^{36}$, Cartas de Cabildos $^{37}$ y Ordenanzas Municipales ${ }^{38}$, deben ser necesariamente complementadas con otra muy numerosa y variada documentación, tanto de carácter institucional como particular, tanto local como imperial, tanto de carácter económico como gubernativo, legislativo, judicial, militar o eclesiástico. Pueden utilizarse como ejemplo los estudios específicos de las haciendas municipales de la Córdoba peninsular o del ayuntamiento de Guanajuato en Nueva

${ }^{35}$ CAÑO ORTIGOSA, José Luis. Las fuentes judiciales para el estudio... Op. cit., pp. 192-213; Sirva como ejemplo de su utilización ALBI RODRíGUEZ, María de los Reyes. El Cabildo de Zacatecas como institución política, económica y social (1550-1650) [tesis doctoral]. Universidad de Sevilla, 2015, pp. 428-446.

${ }^{36}$ A modo de ejemplo Actas de Cabildo que se pueden encontrar publicadas véase: OROZCO Y BERRA, Manuel. Actas de Cabildo de la Ciudad de México. México: Aguilar e Hijos, 1889-1911; OTERO D'COSTA, Enrique (comp.). Primer libro de actas del cabildo de la ciudad de Pamplona en la Nueva Granada, 1552-1561. Bogotá: Academia de la Historia, 1950; Concejo Provincial de Trujillo. Actas del Cabildo de Trujillo. Lima, 1969; Archivo Histórico de Guayas. Actas del cabildo colonial de Guayaquil. Guayaquil: Archivo Histórico de Guayas, 1972; MÁLAGA MEDINA, Alejandro. Índice del libro segundo de Actas de Sesiones y Acuerdos del Cabildo de la Ciudad de Arequipa 1546-1556. Arequipa: el Sol, 1974; Cabildo de Caracas. Actas del cabildo de Caracas. Caracas: Tip. Vargas, 1975; PAZOS PAZOS, María Luisa Julia. Guía de las actas de cabildo de la ciudad de México 17661775. México: Universidad Iberoamericana, 1981; HOYO, Eugenio del. Primer Libro de Actas de Cabildo de las minas de Zacatecas, 1557-1586. Zacatecas: Edición del Ayuntamiento, 1990; Archivo Municipal de Quito. Actas del Cabildo Colonial de San Francisco de Quito. Quito: Archivo Metropolitano de Historia, 1998.

${ }^{37}$ Para la importancia de las cartas de cabildo véase: HEREDIA HERRERA, Antonia. La carta como tipo diplomático indiano. Anuario de Estudios Americanos. 1977, vol. XXXIV, pp. 65-95; REAL DÍAZ, José Joaquín. Catálogo de las cartas y peticiones del cabildo de San Juan Bautista de Puerto Rico en el Archivo General de Indias (siglo XVI-XVIII). Barcelona: Instituto de Cultura puertorriqueña, 1968; VILA VILAR, Enriqueta; JAVIER ORTIZ DE LA TABLA, Javier y TORRES RAMIREZ, Bibiano. Cartas de cabildos hispanoamericanos: Audiencia de Guatemala. Sevilla: Escuela de Estudios Hispanoamericanos, 1984; VILA VILAR, Enriqueta, y SARABIA VIEJO, María Justina. Cartas de cabildos hispanoamericanos. Audiencia de México. Sevilla: Escuela de Estudios Hispanoamericanos, 1985; RODRÍGUEZ MOREL, Genaro. Cartas de cabildo de la ciudad de Santo Domingo en el siglo XVI. Santo Domingo: Patronato de la ciudad colonial de Santo Domingo, 1999.

${ }^{38}$ Ordenanzas de diferentes municipios indianos se encuentran publicadas o estudiadas, por ejemplo: LOHMANN VILLENA, Guillermo. Las ordenanzas municipales de Lima (1533-1635). Separata del III Congreso del Instituto Internacional de Historia del Derecho Indiano. Madrid: Instituto Nacional de Estudios Jurídicos, 1973; DOMÍNGUEZ COMPANY, Francisco. Ordenanzas municipales hispanoamericanas. Madrid; Caracas: Asociación Venezolana de Cooperación Intermunicipal; Instituto de Estudios de Administración Local, 1982; LAVIANA CUETOS, María Luisa. Las Ordenanzas municipales de Guayaquil, 1590. Anuario de Estudios Americanos. 1983, vol. XL, pp. 39-69; Como trabajo que ha utilizado como fuente primaria las ordenanzas municipales para el estudio del cabildo véase: ENCISO CONTRERAS, José. Zacatecas en el siglo XVI. Derecho y sociedad colonial. Zacatecas: Ayuntamiento de Zacatecas, 2000. 
España, ambos en el siglo XVIII, para darse cuenta de que el uso exclusivo de esos tipos documentales resulta incompatible con los objetivos que se buscan al investigar las cuentas municipales de cualquier municipio del imperio español. Si bien, en el caso de existir esos documentos son, desde luego, de obligada consulta, toda vez que suelen ofrecer una información exhaustiva de lo que los cabildantes querían dejar plasmado de sus actuaciones. Además, suelen incluir originales 0 copias de otros documentos generados por diversas instituciones, locales, regionales o centrales, que afectaban a la gestión del municipio ${ }^{39}$.

Asimismo, debemos aclarar que, aunque desde ciertos enfoques podría resultar una explicación mucho más ordenada y racional la clasificación de las fuentes primarias según los tipos de archivos que las custodian, lo cierto es que para este trabajo lo consideramos de poca utilidad, toda vez que muchas de las fuentes que se van a mencionar suelen aparecer en repositorios distintos a los que, por algunas lógicas metodológicas, les correspondería. Evidencia de la afirmación anterior es este mismo trabajo, donde pueden comprobarse los repositorios utilizados para encontrar documentación que ejemplifica lo expuesto, como son el Archivo Histórico de la Universidad de Guanajuato, el Archivo Municipal de Burgos, el Archivo General de la Nación de México, el Archivo General de Indias o la Biblioteca Virtual Miguel de Cervantes. Por tanto, a la vista de lo expuesto, iremos mencionando tipologías documentales en el orden que, según creemos, se hace necesario para poder llegar a un análisis certero de las cuentas de cada municipio de la América española, de las posibilidades que tenían sus recursos y de la gestión que de ellos se hicieron.

\subsection{Legislación y gobierno}

Lógicamente, lo primero y esencial para entender la actuación de los distintos cabildos indianos en cuanto a la gestión de sus haciendas municipales, si es que disfrutaban de ellas -lo que no siempre ocurría-, es analizar las normas que los regulaban. En este sentido, debe recordarse que entre dichas normas se encontraban tanto las dictadas de forma general para todas las localidades indianas por parte de la Corona como las disposiciones particulares de ésta para algunos municipios concretos $y$, por supuesto, las ordenanzas particulares de cada ayuntamiento ${ }^{40}$. En este caso, ese adjetivo "particulares" cobra especial importancia, toda vez que el contenido, forma y estructura de redacción, aprobación e incluso su propia existencia, dependieron en gran medida de cada cabildo. Podrían mencionarse las peculiaridades de las ordenanzas de los concejos chilenos en el siglo XVII, estudiadas por Bertelsen Repetto ${ }^{41}$. Así, el Consejo de Indias ya le

\footnotetext{
39 POZAS POVEDA, Lázaro. Ciudades castellanas... Op. cit., pp. 4 y 6-7; CAÑO ORTIGOSA, José Luis. Fuentes documentales para el estudio del Cabildo de Guanajuato, 1656-1770. Temas Americanistas. 2009, n. 29, pp. 4-23; BELMONTE LÓPEZ, María del Carmen [et al.]. Las actas capitulares como fuente para la historia urbana. En: La ciudad hispánica, siglos XIII al XVI. Madrid: Universidad Complutense, 1987, pp. 39-68; CARRERA STAMPA, Manuel. Las actas capitulares, fuente de la historia de México. En: ALTAMIRA Y CREVEA, Rafael [et al.]. Contribuciones a la Historia Municipal de América. México: Instituto Panamericano de Geografía e Historia, 1951, p. 135.

40 DOMÍNGUEZ COMPAÑY, Francisco. Madrid; Caracas: Asociación Venezolana de Cooperación Intermunicipal, 1982.

${ }^{41}$ BERTELSEN REPETTO, Raúl. El concepto de Ordenanza en el Derecho emanado de los Cabildos chilenos en el siglo XVII. Justicia, sociedad y economía en la América española. Valladolid:
} 
recordaba a la Audiencia de Chile en 1790, haciendo una síntesis de la dinámica de gestión de los caudales de propios y arbitrios que debía seguirse según lo ordenado desde el siglo XVI, que eran los mayordomos de cada ciudad los que debían dar cuenta anual de ellos, entregando esas cuentas a los oficiales de las Cajas Reales, así como los sobrantes. Esas sobras de dinero, en el caso de que las hubiera, debían llegar finalmente a las manos de los presidentes, gobernadores y virreyes, para que éstos las remitieran a la península, en el caso de finales del siglo XVIII por vía reservada.

En efecto, en este ejemplo que utilizamos el Consejo de Indias no hacía más que reafirmar las disposiciones dictadas en el Título XIII, Libro IV, de las Leyes de Indias. Unas disposiciones que, además, se imponían sobre cualquier ordenanza de Intendentes que pudiera contradecirlas, como por ejemplo y con especial atención en la ordenanza $V$ y en las comprendidas entre la XXIII y la $L$ de las de Intendentes de Buenos Aires, haciendo lo propio con la ordenanza VI y las comprendidas entre la XXVIII y la LIV de las de Intendentes de Nueva España. En resumen, lo estipulado en el Título XIII era sencillo, pues excluía la necesidad de intervención de la Contaduría General para controlar el ramo municipal, responsabilidad única de los mayordomos, procuradores o depositarios, según el ayuntamiento, encargados de administrarlos. En efecto, distintas figuras que podían ser nombradas para ese cometido, aunque lo más habitual fuera la figura del mayordomo, como en Santiago de Guatemala, uno de los ayuntamientos que estructuralmente más parecido tuvo con los metropolitanos a lo largo de los siglos de colonización ${ }^{42}$. De hecho, esa circunstancia de multiplicidad de cargos no suponía una anormalidad, puesto que las autoridades virreinales conocían perfectamente esta práctica e, incluso, en el caso de algunos ayuntamientos, ni siquiera se designaba una persona para la administración de los propios, decidiendo tenerlos constantemente arrendados, como sucedió en Cartagena de Indias en el siglo $\mathrm{XVII}^{43}$.

Tanto es así que se marcaba la necesidad de hacer lo que dictaran en cada ciudad sus ordenanzas municipales, que debían haber sido revisadas y aprobadas por la Corona, tal y como se señaló desde el reinado de Felipe II con órdenes como las de 1573 y $1596^{44}$. Eso sí, diferenciando las recaudaciones extraordinarias y que excedieran de ciertas cantidades, partidas para cuya gestión se debía obtener la aprobación previa de la Audiencia correspondiente 0 , en su defecto, la del Gobernador de la región. Finalmente, el mayordomo municipal estaba obligado a dar memoria anual de las cuentas del ramo y presentarla junto al caudal sobrante a los oficiales reales de la Caja a cuya jurisdicción perteneciera, siendo también necesaria su revisión posterior por parte de un oidor de la Audiencia de turno. Acabados todos esos trámites, la Audiencia o el virrey tenían la obligación de incluir la información entre los documentos a remitir a la metrópoli, expresando claramente el "producto de

\footnotetext{
Universidad de Valladolid, 1983, pp. 197-203.

${ }^{42}$ SANTOS PÉREZ, José Manuel. Élites, poder local y régimen colonial: El Cabildo y los regidores de Santiago de Guatemala 1700-1787. Cádiz: Universidad de Cádiz, 1999, p. 118.

${ }_{43}$ BORREGO PLÁ, María del Carmen. Felipe $V$ y Cartagena de Indias: cabildo, crisis y desmembramiento. En: NAVARRO GARCÍA, Luis (coord.). Élites urbanas en Hispanoamérica (De la conquista a la independencia). Sevilla: Universidad de Sevilla, 2005, p. 290.

${ }^{44}$ Recopilación, ley IV, tit. XIII, lib. IV y ley XII, tit. IX, lib. IV.
} 
las mismas, su distribución y las consecuencias". Todo acababa cuando la Corona aprobaba esas cuentas, considerándolas finalmente como buenas y aceptadas ${ }^{45}$.

Ahora bien, sin dejar de lado todas esas normas generales, se fueron añadiendo disposiciones particulares según los lugares y el momento, que perfilaban de manera más concreta el modo de actuación en cada localidad de las Indias. De esta manera, por seguir el ejemplo utilizado anteriormente, se le recordaba a la Audiencia de Chile que tampoco debía olvidar la Orden de 11 de noviembre de 1787 por la que, para aquel territorio, los ayuntamientos debían cesar en la gestión de las rentas superiores de Hacienda que, de forma precisa, se había señalado que correspondían únicamente a la jurisdicción de las Audiencias. Del mismo modo, además de dictar normas generales para ayuntamientos concretos, las autoridades superiores también podían interferir con órdenes precisas para momentos determinados o actuaciones urgentes. Así, pues, la casuística también en este aspecto es enorme. Sirva de ejemplo el caso guanajuatense, cuando en 1722 el virrey marqués de Valero instó al procurador general de la villa a que utilizara el dinero que fuera necesario de los propios que él guardaba para la limpieza del río, de manera que se evitaran inundaciones en la estación de lluvias ${ }^{46}$. Sea como fuere, en lo relativo al interés de este trabajo, lo que muestra todo ello es la importancia del conocimiento y el manejo de las fuentes dictadas por las autoridades imperiales a la hora de comprender las posibilidades y las formas de administración de los propios y arbitrios en cada cabildo concreto de la América española.

También esas ordenanzas municipales que se mencionaban más arriba debían ser aprobadas por la Corona para ser reconocidas como válidas ${ }^{47}$. No obstante, si bien todas esas normas existían, lo cierto es que fue habitual que su aplicación se amoldara más a los intereses particulares de los capitulares que las utilizaban que a la obligación de obedecerlas ${ }^{48}$. Y ello incluso cuando, en muchos casos, refiriéndonos a las ordenanzas propias del concejo, habían sido redactadas, corregidas y reformadas en función de esos mismos intereses de la élite local. El caso es que una vez en funcionamiento se comenzaba una dinámica de actuación que llegaba a normalizarse, y esta dinámica podría identificarse como distinta en cada ayuntamiento colonial. Así, en Guanajuato, para los gastos habituales y periódicos no había necesidad de que el responsable de las cuentas recibiera un

\footnotetext{
${ }^{45}$ Real Orden a la Audiencia de Chile de 5 de abril de 1790. AGI, Indiferente General, 1699.

${ }^{46}$ Acta de cabildo, Guanajuato, 19 de mayo de 1723 y Memoria de las cuentas de propios de 1722. AHUG, Actas de Cabildo, 1721-1732.

${ }^{47}$ RAHN PHILLIPS, Carla. Las ordenanzas del ayuntamiento de Ciudad Real en 1632: retrato de una ciudad en las llanuras. Chronica Nova. 1989, n. 17, pp. 417-439; ZABALZA SEGUIN, Ana. Las ordenanzas locales como fuente para el estudio de la demografía navarra. En: NADAL OLLER, Jordi (coord.). La evolución demográfica bajo los Austrias. Alicante: Instituto de Cultura Juan Gil-Albert, 1991, pp. 127-133; HIJANO PÉREZ, Ángeles. El pequeño poder. El municipio en la Corona de Castilla: siglos XV al XIX. Madrid: Fundamentos, 1992. CLAVERO, Bartolomé. Sevilla, Concejo y Audiencia: Invitación a sus ordenanzas de justicia. Ordenanças de la Real Audiencia de Sevilla. Impreso en Sevilla por Bartolomé Gómez, año 1603. Sevilla: Diputación; Universidad; Fundación El Monte, 1995.

${ }^{48}$ BERNARDO ARES, José Manuel de. Corrupción política y centralización administrativa. La hacienda de propios en la Córdoba de Carlos II. Córdoba: Universidad de Córdoba, 1993. Del mismo autor: Presión fiscal y bienes de propios a principios del siglo XVII. Axerquía. Revista de estudios cordobeses. 1981, n. 2, pp. 129-142.
} 
permiso explícito por parte de la sala capitular para hacer efectivo cada uno ellos, pero sí para otros que, por su carácter concreto, necesitaban del beneplácito de la junta de cabildo. A modo de ejemplo puede citarse la orden de pago que recibió el procurador general de esa misma localidad en 1726 para entregar 150 pesos al regidor encargado de buscar granos por la región y otros 25 pesos al escribano que le acompañara ${ }^{49}$.

A pesar de todo, y aun cuando se demuestra con la línea argumental anterior, tampoco se debe olvidar que los municipios no tenían total libertad para administrar sus propios y arbitrios, toda vez que para gastos de envergadura debían solicitar la aprobación real. Un extremo éste último que ninguna legislación, ni local ni imperial, ponía en duda. Ello resulta bastante evidente sobre todo a partir del fenómeno iniciado en el siglo XVII con el espectacular crecimiento de iniciativas para la construcción y modernización de edificios e infraestructuras de utilidad pública en las principales ciudades del imperio, además de obras de embellecimiento, abasto e higienización. Las libranzas presupuestarias que requerían obras de ese tipo generaron múltiples expedientes que resultan especialmente ricos a la hora de conocer las cuentas municipales indianas. Pero, tampoco debe olvidarse, este tipo de acciones estaban sujetas a las disposiciones particulares emanadas para ellas, así como las más genéricas para este tipo de acciones, que incluían legislación de carácter gubernativo sobre las autoridades competentes para decidirlas y de carácter económico sobre el origen de los caudales con los que debían pagarse y sus responsables. Ello cobra importancia en este trabajo cuando comprobamos que para tener una visión de todo ese conjunto dispositivo que influía en la obra pública municipal y en sus rentas se acumulan cuerpos legislativos como las Partidas de Alfonso X, la Novísima Recopilación de Castilla o la Recopilación de Indias de 1680, entre otras; sin mencionar las normas dictadas a partir de la implantación de las Intendencias en América o todas las incluidas dentro del conjunto de las emanadas durante el reformismo borbónico en general ${ }^{50}$.

Así, a modo de ejemplo, ciudades como Manila y Guanajuato desembolsaron grandes cantidades de dinero durante los siglos XVII y XVIII para lograr tener los edificios representativos y adecuados a las necesidades de ciudades de la entidad que estaban adquiriendo aquellas. Construcciones como las de las Casas Consistoriales, alhóndigas y otros edificios de abasto, puentes, calzadas, desagües e, incluso, algunas iglesias, fueron emprendidas por el ayuntamiento filipino en menos de una centuria, y todo ello sin tener en cuenta que también corrió a su cargo la fortificación de la ciudad y la reparación de los daños del temblor de $1645^{51}$. Unas enormes cantidades desembolsadas que, necesariamente, no podían ser asumidas sin el permiso de las autoridades superiores, no sirviendo las competencias asignadas al municipio por sus propias ordenanzas, que también necesitaban de

\footnotetext{
${ }^{49}$ Junta de cabildo, Guanajuato, 30 de septiembre de 1726. AHUG, Actas de Cabildo, 1721-1732.

${ }^{50}$ FIGUEROA QUINTEROS, María Angélica. El Cabildo y el régimen jurídico de la construcción de obra pública en Chile indiano. Notas para su estudio. En: Poder y presión fiscal en la América española (siglos XVI, XVII y XVIII). VI Congreso del Instituto Internacional de Historia del Derecho Indiano. Valladolid: Instituto de Cooperación Iberoamericana, 1986, pp. 403-424.

${ }^{51}$ ALVA RODRíGUEZ, Inmaculada. La vida municipal en Manila en los siglos XVI-XVII. Córdoba, universidad de Córdoba, 1997, pp. 133-142.
} 
aprobación real. También Guanajuato se vio inmerso en este movimiento en cuanto tuvo la posibilidad económica de hacerlo, siendo los gastos más importantes del ayuntamiento en el siglo XVIII la construcción de sus Casas Reales, las alhóndigas y las carnicerías municipales. Para ello, el cabildo debió solicitar fuertes préstamos a partir de 1710 y hasta bien entrado el siglo, subastándose en distintas ocasiones el asiento o encabezamiento de gran parte de los ingresos del ramo de propios, es decir, las partidas obtenidas en la alhóndiga y los alquileres de los solares, locales y puestos de venta callejera del municipio ${ }^{52}$.

En consecuencia, los tipos documentales que se generaban son variados. Y es que, si bien los capitulares de un municipio tenían la obligación, desde el momento de la fundación, de redactar dichas ordenanzas, de las cuales debían guardarse copias en el propio archivo del ayuntamiento, éstas, en efecto, debían enviarse como consulta o solicitud a las autoridades superiores antes de ser aprobadas. Esto es, Corregidores, Audiencias, Gobernadores, Virreyes y, finalmente, el Consejo de Indias y el propio rey, aunque no todos eran destinos necesarios. Esas autoridades podían revisar, opinar y aconsejar sobre su aprobación o modificación. Además, teóricamente, a la hora de ser redactadas debían acomodarse a las distintas legislaciones vigentes que las condicionaran, de las cuales también debían tener copia en los municipios para su mejor cumplimiento. Es decir, en modo ideal, las ordenanzas de cada población indiana, si éstas se hubieran creado en todos los casos, deberían encontrarse disponibles para el investigador en archivos correspondientes a todos los estadios administrativos políticos de la Corona Hispánica, desde el repositorio local del municipio que se estudie hasta el Archivo General de Indias donde se conserva la documentación administrativa del imperio, pasando, por supuesto, por archivos regionales o nacionales actuales en función de las autoridades imperiales, de administraciones intermedias como gobernaciones, Audiencias y virreinatos, por donde pudieron transitar previamente a su envío a la Corona. Un ejemplo de este extremo lo constituyen, únicamente por citar uno significativo, las ordenanzas del Cabildo de México ${ }^{53}$.

Un aspecto muy importante de esas normativas que definían a los concejos es que determinaban la propia estructura institucional del ayuntamiento y las funciones exactas de cada uno de sus capitulares, incluyendo los aspectos referidos a la hacienda municipal. En efecto, toda documentación que nos ayude a conocer cómo se estructuraba cada cabildo, cuántos y cuáles eran sus oficios capitulares y qué competencias tenía cada uno de ellos, nos revelará sustanciosa información sobre quiénes eran sus responsables, de qué forma se administraban, qué importancia tenía su gestión en cada lugar y cuáles eran los principales recursos con los que contaba la localidad. Por tanto, las disposiciones y capitulaciones en tiempo de la conquista a favor de descubridores, adelantados y capitanes; las distintas normas en

\footnotetext{
${ }^{52}$ Autos sobre el remate de los propios y rentas del cabildo de Guanajuato, 1714. AGN, Bienes Nacionales, 1650, exp. 20.- Escritura de hipoteca de los propios y rentas que otorga el cabildo de Guanajuato a favor de Domingo Bravo de Laguna, Comisario del Santo Oficio de Irapuato, Guanajuato, 11 de febrero de 1710. AHUG, PCL, 1710, fs. 48v-50.- Poder del cabildo de Guanajuato al procurador general para la obtención de un préstamo de 10.000 pesos, Guanajuato, 4 de diciembre de 1734. AHUG, PCL, 1734, fs. 244-246.

${ }^{53}$ GALÁN LORDA, Mercedes. Ordenanzas del Cabildo de México sobre abastos en el siglo XVIII. Anuario de historia del derecho español. 1997, n. 67, pp. 1315-1338.
} 
forma de reales cédulas y de reales provisiones que fueron emanando a lo largo de la colonización; las distintas leyes generales y recopilaciones dictadas para todas las Indias o para virreinatos y reinos concretos; las órdenes, fueros y mercedes concedidas a poblaciones de manera individualizada; así como los títulos y confirmaciones de oficio de los cargos capitulares de cada concejo, con sus competencias específicas para cada uno de ellos en función de los privilegios y condiciones concretas de sus nombramientos, bien por concesión, venta, transmisión o elección, se convierten en documentos de obligada consulta. Por razones de espacio, y otras que no escapan al lector, no presentaremos aquí un listado de ejemplos de todo lo anterior, pero una prueba de lo expuesto es el hecho de que en 1609 se dictara una Real Pragmática que permitía a los cabildos recuperar todos aquellos oficios capitulares con responsabilidad de cobro de impuestos y gestión de propios y arbitrios que se hubieran arrendado o vendido. $Y$ ello especificando que fueran cuales fueren los privilegios que en cada caso se hubieran concedido para esos oficios, la recuperación de los puestos se haría pagando a sus titulares, beneficiarios o arrendatarios el valor del oficio. Una vez consumado lo anterior pasaría a titularidad del ayuntamiento, pero ya sin los privilegios anteriores sino ajustado a las leyes generales ${ }^{54}$.

De la afirmación anterior se extrae, pues, que, para entender la estructuración, organización y gestión de la hacienda municipal, debe revisarse la documentación que condicionaba la propia fundación o las formas de continuidad colonial de cada localidad indiana. Lógicamente, no viene al caso aquí repasar todas, sino sencillamente recordar que son documentos de obligada consulta en este tipo de investigación siempre que se hayan conservado, de la misma forma que se hace imposible relacionar en este trabajo exhaustivamente todos esos tipos documentales, por su propia naturaleza múltiple, causal y número. En cambio, la legislación dictada de forma general para los municipios, más allá de que se cumpliera en mayor o menor medida, si puede ser enumerada, aunque sólo sea de forma escogida. Así, se hace necesaria la consulta de las distintas disposiciones que se fueron dictando en esta materia, facilitándose este ejercicio con la consulta de las distintas recopilaciones que se fueron haciendo con el pasar de los siglos. Sin duda, la más significativa y útil para nosotros es la Recopilación de 1680, de la que destacaríamos las leyes comprendidas dentro del Libro Cuarto, especialmente los títulos Quinto, Noveno, Décimo y Undécimo, dedicados a las poblaciones, cabildos, oficios concejiles y procuradores, respectivamente. Como también, desde luego, el Título Trece, exclusivo para legislar los propios, arbitrios y pósitos de las poblaciones indianas. También el Libro Quinto incluye legislación importante al respecto, destacando los títulos Tercero, Séptimo y Octavo, sobre alcaldes ordinarios, alguaciles mayores y escribanos de cabildo, respectivamente. Sin dejar de reseñar que se encuentran otras leyes particulares que afectaban a la gestión de las cuentas municipales ${ }^{55}$.

\footnotetext{
${ }^{54}$ Real Pragmática, Madrid, 4 de septiembre de 2009. Biblioteca Virtual Miguel de Cervantes (BVMC), BVMC:275691.

${ }_{55}$ CORONAS GONZÁLEZ, Santos Manuel. Recopilación de Leyes de los Reynos de las Indias. Madrid: Viuda de Joaquín Ibarra, 1791. Quarta Impresión. Edición facsimilar. Madrid: Boletín Oficial del Estado, 1998.
} 


\subsection{Libros de cuentas y protocolos notariales}

Por supuesto, como es evidente al objeto que nos interesa, un tipo de fuente documental que resulta esencial son las series completas de cuentas de cada cabildo indiano. Una documentación que, por la propia naturaleza de algunas leyes ya comentadas más arriba, debería aparecer en diferentes archivos, como los locales, nacionales y en la sección de Contaduría del Archivo de Indias, toda vez que esas cuentas debían ser revisadas y aprobadas por la Corona. Lamentablemente, es habitual no encontrarlas en ninguno de esos repositorios, bien porque en algún momento fueron destruidas, desaparecieron o, sencillamente, nunca se produjeron. Las más frecuentes, por muchas razones lógicas, suelen ser las formadas durante el siglo XVIII y, especialmente, a finales del período colonial. Se convierte entonces en un verdadero tesoro la aparición de alguna serie o síntesis coetánea de las mismas, aunque sea para un corto período de años. Y es que, al menos, esa poca información suele brindar enormes pistas sobre los fundamentos de los ingresos y de los gastos más habituales, a largo plazo también, de los concejos en esas fechas. Estas cuentas suelen presentarse según el modo de contabilidad propio de la época, también utilizado en otras instituciones propiamente hacendísticas, como las Cajas Reales. Es decir, en libros contables de cargo y data, donde se señalaban por una parte todos los ingresos y sus conceptos y en otra columna los gastos y sus motivos. En este sentido, debe mencionarse que, en numerosas ocasiones, la elección de un orden concreto de presentación de las cuentas, la forma de expresar las distintas partidas, la selección o eliminación de otras en función de la importancia concedida a cada una e, incluso, la estética de presentación -en cuadros de distintas formas y distribuciones, con comentarios explicativos o sin ellos, con anotaciones marginales o no- depende fundamentalmente de los responsables que en cada momento se hacían cargo de ellos y de sus preferencias a la hora de seguir, o no, los modos de sus antecesores. Esta circunstancia era tan común que, en un intento de ordenamiento y racionalización de la presentación de las cuentas municipales, en 1764 se dispuso con concreción la forma en la que los responsables de las finanzas municipales debían redactarlas y exponerlas ${ }^{56}$.

Quizá uno de los ejemplos más sintéticos, esquemáticos y, por qué no decirlo, hermosos, de relación y exposición de propios y arbitrios anuales de una localidad para informar a las autoridades superiores, sea el cuadrante elaborado a fines del siglo XVIII por sus responsables en la ciudad de Arequipa, de cuyo documento se conserva una copia en el Archivo General de Indias. En él, una peculiaridad de esas formas distintas de expresar las cuentas según quienes las elaboraban es el hecho de que los ingresos aparecen indicados como "contribuyentes" y los gastos como "interesados"

\footnotetext{
56 "Demostración de el método con que se han de formar por regla general las cuentas de propios y arbitrios de los pueblos del Reino", desarrollo de la Instrucción de 30 de julio de 1760, Madrid, 13 de marzo de 1764. Disponible en <http://www.bde.es/bde/es/secciones/servicios/Profesionales/Biblioteca/Biblioteca.html>. ${ }^{57}$ Carta del Gobernador de Arequipa, con copia del Reglamento de Propios y Arbitrios de dicha ciudad con su plano aritmético, Arequipa, 13 de marzo de 1787. AGI, Indiferente General, 1699.
} 
Asimismo, debe considerarse que la habitual división que suele hacerse entre propios y arbitrios de un ayuntamiento colonial no necesariamente aparece reflejada en las cuentas del concejo, sino que es el mismo investigador el que debe clasificarlas y relacionarlas según su criterio metodológico. Es decir, en las cuentas municipales, cuando existen, se suelen reflejar las distintas partidas enunciadas según su origen. De esta manera, por ejemplo, aparecen arbitrios cobrados según el producto licenciado para su venta en la población, como los impuestos a las distintas bebidas espirituosas, a la carne, al aceite, a la sal o al carbón; impuestos cobrados por derecho de entrada a la localidad para comerciar, o de paso por un puente cuya construcción fue costeada por el municipio. También la sisa, alcabalas y otras cargas impositivas si esos ayuntamientos las tenían concedidas. Así, en la Audiencia de Charcas muchos concejos tenían la potestad de nombrar a los administradores del ramo de la sisa aplicado a las mercancías que circulaban entre Tucumán, Buenos Aires y Paraguay ${ }^{58}$; mientras que en Nueva España no eran pocos los cabildos con derechos otorgados sobre el cobro de las alcabalas, como el de Guanajuato, que venimos utilizando como ejemplo recurrente.

También asentar los propios, como las rentas generadas por el arriendo de haciendas, dehesas, locales o viviendas urbanas propiedad del concejo, simplemente aparecen indicados particularmente con esos conceptos. Es labor del historiador agruparlas, analizarlas y sacar conclusiones, como por ejemplo el mayor o menor peso de los propios en relación con los arbitrios o del destino de estos ingresos hacia unas prioridades municipales $u$ otras a la hora de gastarlos. Para nosotros, referentes metodológicos para este tipo de labor lo constituyen trabajos como los de Pozas Poveda para el caso la Córdoba peninsular en el siglo XVIII, o el general para todo el continente de Blázquez Garbajosa ${ }^{59}$.

En cualquier caso, para un análisis profundo con conclusiones críticas y válidas no debe obviarse la consulta de otras fuentes que, directamente, aportan información sobre muchas de esas mismas partidas de ingresos municipales. En efecto, el cobro de derechos e impuestos por parte de asentistas, arrendatarios o por el propio municipio, la gestión de bienes inmuebles, los ingresos de determinados oficios municipales por el ejercicio de su función, como cobros por medir pesos, custodiar granos o ganado, imponer sanciones de orden público, etc., solían originar unas cuentas y documentos concretos de cada una de esas partidas por parte de sus responsables, que luego presentaban al encargado municipal de llevar la contabilidad de propios y arbitrios, normalmente denominado mayordomo, procurador o depositario de bienes de propios. En este apartado merece la pena detenerse para hacer un inciso con respecto a la importancia, cantidad y variedad de documentación que generaban los impuestos municipales, y muy especialmente los arbitrios que fiscalizaban el transporte, la entrada y salida, el almacenaje, el trato o el

\footnotetext{
${ }^{58}$ PAZ, Gustavo L. y SICA, Gabriela. La frontera oriental del Tucumán en el Río de la Plata (siglos XVI-XVIII). En: TRUCHUELO, Susana. Las fronteras en el mundo atlántico: (Siglos XVI-XIX). La Plata: Universidad Nacional de La Plata, 2017, pp. 301-305.

${ }^{59}$ POZAS POVEDA, Lázaro. Ciudades castellanas... Op. cit., pp. 83-256; BLAZQUEZ GARBAJOSA, Adrián. Ensayo de clasificación metodológica de los bienes de propios. En: Actas de las II Jornadas de metodología y didáctica de la Historia. Historia Moderna. Cáceres: Universidad de Extremadura, 1983, pp. 147-157.
} 
consumo de productos más o menos básicos y habituales. Y es que, los concejos españoles, tanto peninsulares como coloniales, tendieron a implantar un gran número de éstos últimos, como forma de conseguir los ingresos necesarios para hacer frente a las deudas contraídas o a la imposibilidad de recaudar parte importante de los caudales comprometidos con arrendadores o beneficiarios del cobro de los impuestos directos concedidos en subastas o por cualquier otro método de cesión pública. Hasta el punto de suponer todos esos ingresos impuestos de forma extraordinaria, en la mayor parte de los principales ayuntamientos, más de la mitad del monto total de sus ingresos ${ }^{60}$.

Es decir, las cuentas del cabildo, en muchos casos, son la suma, síntesis y ordenamiento de una serie de numerosas y variadas contabilidades particulares que, en ocasiones, podrán coincidir o no entre ellas. De esta forma, no es raro encontrarse que los responsables de las cuentas municipales hicieran sus propias previsiones presupuestarias en función de lo que, aproximadamente, debían obtener según los distintos conceptos de ingresos, y que estas previsiones no coincidieran con las cantidades que finalmente les llegaban, o que declaraban que llegaban. De la misma manera que tampoco es extraño que las cifras entre unas contabilidades específicas y las reflejadas en los libros generales de los cabildos sean dispares. Un extremo este que se repetía, en ocasiones, entre estas mismas cuentas y las que también aparecen recopiladas de cada ayuntamiento por los oficiales de las Cajas Reales, Tribunales de Cuentas, Gobernadores, fiscales de Audiencias o jueces de los Consejos ${ }^{61}$. Autoridades que también generaron, pues, documentación contable e informativa de los propios y arbitrios municipales, y a las que desde fines del siglo XVIII se añaden los papeles de ministros, intendentes, subdelegados e inspectores, entre otros ${ }^{62}$.

Igualmente, se antoja absolutamente necesaria la consulta de las escrituras notariales, tanto las específicas de los escribanos de los cabildos, más ricas normalmente a los efectos que nos ocupan, como las de otros notarios públicos en los que pudieran haberse escriturado distintos contratos de compra y venta, obligaciones, censos, arrendamientos, nombramientos, poderes, licencias, etc., concernientes al ayuntamiento o a los capitulares. En este sentido, las escrituras generadas por los escribanos de cabildo, en su función, no tienen mayor necesidad de explicación por resultar obvia. No obstante, es posible que se entienda mucho mejor su importancia si exponemos la iniciativa adoptada en Guanajuato en 1732, que limitaba bastante la autonomía con la que frecuentemente vemos actuar en las Indias a los responsables de las finanzas municipales. En efecto, el cabildo guanajuatense tomó la decisión de controlar y racionalizar la labor de administración de los propios, adoptando una serie de medidas, como designar a varios regidores para elaborar una relación actualizada de los bienes y rentas municipales, así como del estado que presentaban en ese momento. Además, se estipuló que el escribano

\footnotetext{
${ }^{60}$ GARCÍA GARCÍA, Carmen. El reformismo borbónico... Op. cit., pp. 55-56.

${ }^{61}$ SÁNCHEZ BELLA, Ismael. La organización financiera de las Indias, siglo XVI. Sevilla: Escuela de Estudios Hispanoamericanos, 1968, pp. 318-325.

${ }^{62}$ Para conocer mejor las fuentes relativas a las cuentas fiscales de organismos generales del imperio véase, GALARZA, Antonio Facundo. Las fuentes fiscales del imperio español en América: de las cartas-cuentas a los libros de tesorería. REFA. Revista Electrónica de Fuentes y Archivos. 2019, n. 10, pp. 96-113.
} 
de cabildo debía estar también informado de las cuentas, y que este las copiara en tres libros distintos, uno para asentar "todas las haciendas, casas y demás bienes que se acensuaren o hipotequen", otro para la alhóndiga, donde debían anotarse las cantidades y los precios de todos los granos y harinas que entraban y salían y, el tercero, para registrar todos los libramientos del cabildo. Por último, la junta municipal creyó oportuno la fabricación de una caja de tres llaves en la que debería guardarse el dinero del ayuntamiento, llaves que custodiarían el alcalde mayor, el regidor más antiguo y el procurador general. No obstante, finalmente sería el escribano el que asumiría la custodia de una de las llaves, como consta que ya ocurría en $1759^{63}$.

En cuanto a la revisión de las escrituras del resto de notarios de las poblaciones, quizá pudiera parecer excesivo indagar en las de los capitulares, como particulares, pero a este efecto debe recordarse la bastante bien conocida confusión entre lo público y lo privado en el ejercicio del poder durante el Antiguo Régimen. Únicamente por citar un caso que evidencia lo que decimos podemos referirnos a lo sucedido en Guanajuato en 1744, donde el nuevo procurador de la ciudad, encargado de las rentas municipales, finiquitó un crédito de 4.000 pesos que el ayuntamiento le debía a él mismo, que lo concedió de su caudal privado aunque en representación de la diputación de comercio ${ }^{64}$. Sea como fuere, no nos detendremos en la explicación profunda de este tipo de confusión, toda vez que ya ha sido tratado en otros estudios anteriores que hemos citado anteriormente.

De esta manera, no resulta raro que porcentajes o totales de los ingresos obtenidos por el cobro de derechos, impuestos, penas o cualquier otro motivo relacionado con el ejercicio de alguno de los cargos públicos municipales fuera directamente a las arcas del dueño o adjudicatario del oficio. Como tampoco es extraño que parte de los gastos fueran asumidos también por el caudal particular de esos responsables e, incluso, que las cuentas de todo ello aparezcan únicamente entre la documentación particular de quienes los ejercieron. Así, incluso, es habitual que las propias escrituras de los escribanos de los cabildos se mantuvieran custodiadas en sus propias casas, pasando finalmente a ser parte de la propiedad de sus archivos particulares. Del mismo modo, las cuentas por las penas impuestas por alguaciles mayores, mantenimientos de cárcel por parte de los carceleros, cobros llevados a cabo por fieles ejecutores, cantidades acumuladas por derecho de custodia de montos de dinero por parte de depositarios generales, censos comprometidos a cargo de los concejos, pero escriturados por alguno de sus capitulares a modo particular a cambio de la gestión de algún oficio, asiento, impuesto o renta municipal, etc., ofrecen una enorme información sin la cual se hace difícil entender las finanzas de algunos municipios.

\footnotetext{
${ }^{63}$ Junta de cabildo, Guanajuato, 30 de abril de 1732. Archivo General del Gobierno del Estado de Guanajuato (AGGEG en adelante), Libro de Becerro, sin catalogar, primera escritura, fs. 1-2.Confirmación del oficio de escribano público y de cabildo de la ciudad de Guanajuato a favor de Alonso Calderón, 12 de mayo de 1760. AGI, México, 1.196.

${ }^{64}$ Escritura de cancelación de deuda, Guanajuato, 23 de diciembre de 1744. AHUG, PCL, 1744, fs. 311-312.
} 


\section{Fuentes primarias de carácter secundario}

Antes de iniciar este apartado queremos dejar señalado que, si bien se han clasificado como de carácter secundario, algunos tipos documentales de los que veremos a continuación, y según la cantidad y calidad que se encuentren de cada uno de ellos, pueden llegar a ser los únicos conservados o los que más información aporten sobre nuestro objeto de estudio. Dicho de otra forma, no se debe descartar que la casuística investigadora llegue a identificar alguna de estas tipologías como la esencial a la hora de describir las cuentas municipales de una localidad concreta de la América española. Es el caso que nos sucedió a nosotros cuando investigamos el cabildo de Guanajuato, donde se mostraron útiles y fundamentales las escrituras notariales y las judiciales, debido a la desaparición sistemática de sus Actas Capitulares, de su correspondencia y de sus Ordenanzas municipales ${ }^{65}$.

\subsection{Fuentes judiciales}

En efecto, las fuentes judiciales en muchos casos resultan esclarecedoras, debido a los frecuentes conflictos que se generaban entre las instituciones y entre estas y los particulares, tanto por los cobros de los distintos impuestos, derechos, rentas, licencias, etc., como por su posterior gestión y gasto. En numerosas ocasiones, dentro de los procesos judiciales derivados de esa actividad económica de los ayuntamientos, e incluso en otras que sencillamente servían como apoyo argumental, se debieron presentar informaciones concernientes a las cuentas municipales, dejando testimonio documental de ellas. Obviamente, como el resto de las fuentes, estas deben ser criticadas en su manejo, toda vez que se presentaban como información de parte, señalando o remarcando solo lo que a esa parte importaba. Incluso, cuando la solicitud de la información se originaba en un auto del juez competente, los responsables de elaborar el informe, o la copia solicitada, debían tener mucho cuidado de aportar los datos que no les supusieran ningún problema añadido a ellos, lo que deriva en ausencias o en descuadre, bien con la realidad o bien con otros documentos de manejo interno o personal.

Aparte, tampoco son escasas las fuentes derivadas de los propios procesos ordinarios de inspección de la labor de los responsables de las cuentas municipales. En este apartado podrían incluirse, además de las ya vistas con anterioridad sobre la obligada presentación de informes a instituciones económicas y de gobierno superiores, los mecanismos de control como las visitas y los juicios de residencia, haciendo de algunas secciones de archivos verdaderas minas informativas, como lo es la sección de Escribanía de Cámara del Archivo General de Indias. Así se ha demostrado, por ejemplo, para el estudio de los propios de ciudades como La Habana y Santiago de Cuba, donde la escasez de otro tipo de fuente, acompañado de la riqueza que presentan para este aspecto las de este tipo, han permitido profundizar en el conocimiento de sus cuentas municipales ${ }^{66}$. $Y$ es que, efectivamente, durante estos procesos judiciales era normal la denuncia e inspección de las cuentas locales, origen y objeto de disputas en no pocas

\footnotetext{
${ }^{65}$ CAÑO ORTIGOSA, José Luis. Las fuentes judiciales para el estudio... Op. cit., pp. 192-213.

${ }^{66}$ CASTILLO MELÉNDEZ, Francisco. La hacienda municipal indiana: el caso de La Habana y Santiago de Cuba hasta 1700. Anuario de Estudios Americanos. 1985, n. 42, pp. 501-547.
} 
ocasiones. Más allá de que, además, en casos como los juicios de residencia, que a su llegada se les hacía a los alcaldes mayores, corregidores o autoridades que presidieran los cabildos por parte de los capitulares, los costes repercutían sobre las mismas cuentas municipales ${ }^{67}$. En el caso de las visitas tampoco necesitaremos abundar en su importancia, toda vez que es bien conocida la riqueza informativa de la documentación que generaban, de las formas y bondades de su análisis, además de la evidencia de su capacidad de transformar y condicionar las formas habituales de actuar de las distintas administraciones públicas municipales una vez que estas sufrían una inspección de este tipo, como el ejemplo de la visita de Gálvez a la ciudad de Guanajuato en 1770 que ya referimos anteriormente ${ }^{68}$.

\subsection{Fuentes eclesiásticas}

Pero, además de las visitas llevadas a cabo por parte de autoridades políticas y judiciales, también deben tenerse en cuenta las visitas de carácter eclesiástico, al igual que numerosa cantidad de documentación referida a imposición de censos, subvención y patronazgo de instituciones y actividades religiosas de carácter sanitario, educativo, asistencial, caritativo o devocional, entre otras. De ello, para el caso de Santiago de Chile ya dio buena cuenta Avila Martel, un lugar donde el cabildo llegó a imponer un arancel eclesiástico y salarios a algunos curas ${ }^{69}$. Tampoco fueron escasas las solicitudes de préstamos llevadas a cabo por los ayuntamientos para hacer frente a sus necesidades o urgencias, siendo ciertas instituciones eclesiásticas las principales entidades prestamistas de las colonias ${ }^{70}$.

\footnotetext{
${ }^{67}$ MARILUZ URQUIJO, José María. Ensayo sobre los juicios de residencia indianos. Sevilla: Escuela de Estudios Hispanoamericanos, 1952; ANDÚJAR CASTILLO, Francisco; FEROS, Antonio y PONCE LEIVA, Pilar. Corrupción y mecanismos de control en la Monarquía Hispánica: una revisión crítica0 Tiempos Modernos. 2017, vol. 8, n. 35, pp.284-311. JIMÉNEZ JIMÉNEZ, Ismael. Una herramienta inútil. Juicios de residencia y visitas en la Audiencia de Lima a finales del siglo XVII. Temas Americanistas. 2015, n. 35, pp. 60- 87; MORENO AMADOR, Carlos. El valor del Juicio de Residencia como fuente documental: estructura, características y peculiaridades. El paradigma de Tabasco en la segunda mitad del siglo XVIII. En: CAÑO ORTIGOSA, José Luis y VASSALLO, Jaqueline (coords.). "Dossier Las fuentes judiciales en el Americanismo: Instituciones, archivos, sujetos y desafíos metodológicos". Temas Americanistas. 2019, n. 42, pp. 160-191.

${ }^{68}$ Para las Visitas sirvan de referencia algunos textos clásicos, como ZUMALACARREGUI, Leopoldo. Visitas y residencias en el siglo XVI. Unos textos para su distinción. Revista de Indias. 1946, n. 26, pp. 917-921. SÁNCHEZ BELLA, Ismael. Visitas a Indias (siglos XVIXVII).en: Derecho indiano: estudios. Pamplona, EUNSA, 1991. Del mismo autor: Visitas a la Audiencia de. México (siglos XVI y XVII). Anuario de Estudios Americanos. 1975, n. 32, pp. 375-402. Del mismo autor: El Juicio de Visita en Indias. En: IV Congreso del Instituto Internacional de Historia del Derecho Indiano. México: IIHDI, 1976, pp. 579-626. MOLINA ARGÜELLO, Carlos. Las visitas-residencias y residencias-visitas de la Recopilación de Indias. Caracas: Academia Nacional de la Historia, 1975. MALAGÓN PINZÓN, Miguel. Las visitas indianas, una forma de control de la administración pública en el estado absolutista. Vniversitas. 2004, n. 108, pp. 821-838.

${ }^{69}$ AVILA MARTEL, Altamiro. Actividades del Cabildo secular de Santiago en el campo eclesiástico durante el siglo XVI. En: Estructuras, gobierno y agentes de administración en la América española. Valladolid: Instituto de Cooperación Iberoamericana, 1984, pp. 9-42.

${ }^{70}$ LAVRIN, Asunción y BAUER, Arnold Bauer. La Iglesia en la economía de América Latina Siglos XVI al XIX. México: Instituto Nacional de Antropología e Historia, 1986; MARICHAL, Carlos. La Iglesia y la crisis financiera del virreinato, 1780-1808: apuntes sobre un tema viejo y nuevo. Revista Relaciones de Historia y Sociedad. 1989, n. 40, pp. 103-129; VON WOBESER, Gisela. Mecanismos crediticios en la Nueva España el uso del censo consignativo. Estudios mexicanos. 1989, n. 1, pp. 1-23; de la misma autora: El crédito eclesiástico en la Nueva España, siglo XVIII. Revista América Latina en la
} 
Un extremo que no debe asociarse únicamente a los reinos indianos de la Corona, sino que era la tónica general en los municipios de todo el imperio desde el siglo $\mathrm{XVI}$, en el que empezó a producirse un trasvase generalizado de las deudas municipales desde las oligarquías locales al estamento eclesiástico, como ha sido bien demostrado para el caso, por ejemplo, de la Corona de Aragón $n^{71}$.

Como muestra de esta intensa actividad de los responsables de las finanzas municipales buscando créditos puede citarse el ayuntamiento de Guanajuato en el siglo XVIII. Allí, los encargados de las cuentas eran los procuradores generales del cabildo, quienes solían recibir poderes de esta institución para esos fines, a la vez que otros capitulares actuaban como avalistas. Poderes como los otorgados por el cabildo en 1742 a favor del procurador general para la localización de alguien que pudiera prestar al consistorio los 12.000 pesos necesarios para la compra de granos así lo atestiguan. Una vez encontrada la persona o la institución dispuesta a otorgar el crédito, él mismo podía realizar todos los trámites oportunos, incluyendo la firma de la hipoteca correspondiente y el compromiso de pago de las rentas o réditos pertinentes, generando una serie de documentos que hoy podemos rastrear para entender esas cuentas del municipio ${ }^{72}$. Tanto es así que, a poco que se indague, pueden seguir localizándose más de ellos, como el otorgado en 1757 con ocasión de la solicitud de los 40.000 pesos que precisaba el cabildo para hacer frente a sus necesidades dinerarias ${ }^{73}$.

En Guanajuato, pues, los poderes dados a los procuradores para obtener préstamos o escriturar censos, normalmente con instituciones eclesiásticas de la región, fueron habituales, al igual que en otras muchas poblaciones indianas. Allí, algunas hipotecas del consistorio las formalizó el procurador general, poniendo como garantía de pago sus propios bienes personales. Pero lo cierto es que la costumbre, establecida a favor de los capitulares, fue hipotecar las rentas de propios del ayuntamiento, para lo cual se necesitaba un permiso especial del virrey. Es lo que acaeció en 1747 ante la necesidad que tenía el consistorio de obtener urgentemente 12.000 pesos para la construcción de dos puentes, reparar y ampliar la cárcel y asegurar el abasto de maíz en la ciudad. El año anterior ya se había pedido la licencia del virrey para la obtención del crédito, el cual otorgó bajo la condición del cumplimiento estricto de las leyes, es decir, que se hiciera con el aval de los bienes de los regidores. Pero estos se negaron, prefiriendo no recibir el dinero a hipotecarse, por lo que solicitaron de nuevo la autorización para obtener el crédito, pero con la garantía de las rentas municipales, que solían dejar de beneficio unos

\footnotetext{
Historia Económica. 1994, n. 6, pp. 9-19; MARTíNEZ LÓPEZ-CANO, María del Pilar. La Iglesia y el crédito en Nueva España: entre viejos presupuestos y nuevos retos de investigación. En: MARTíNEZ LÓPEZ-CANO, M. (coord.). La Iglesia en Nueva España. Problemas y perspectivas de investigación. México: Universidad Nacional Autónoma de México; Instituto de Investigaciones Históricas, 2010, pp. 303-352; MARULANDA RESTREPO, Juan Sebastián. Instituciones eclesiásticas y crédito en Antioquia, siglo XVIII. Revista Historia y Sociedad. 2016, n. 31, pp. 171-203.

${ }^{71}$ MATEOS ROYO, José Antonio. Propios, arbitrios y comunales: la hacienda municipal en el Reino de Aragón durante los siglos XVI y XVII. Journal of Iberian and Latin American Economic History. 2003, año 21, n. 1, pp. 51-78.

72 Poder especial del cabildo de Guanajuato, 25 de mayo de 1742. AHUG, PCL, 1742, fs. 99v-101 y 119-120v.

${ }^{73}$ Poder especial del cabildo de Guanajuato, 7 de septiembre de 1757. AHUG, PCL, 1757, f. 81v.
} 
3.000 pesos anuales. La necesidad urgente del acometimiento de las obras hizo que el virrey cediera y permitiera la hipoteca del capital público, pero bajo ciertas condiciones, como el depósito del dinero en la Caja Real, la revisión de las cuentas por parte de los oficiales reales y el ingreso de los beneficios anuales del cabildo en la hacienda real. Estas condiciones sí fueron aceptadas por el ayuntamiento y, como era habitual, el procurador general pudo comenzar su labor de búsqueda de la institución o persona que estuviera dispuesta a hacer el préstamo, que finalmente fue el convento de religiosas de Santa Catarina de Siena de Valladolid, pero a partir de la deuda que con dicho convento tenía una vecina de Guanajuato. En virtud de dicha deuda sería la vecina la que adelantaría el dinero al cabildo, por medio de uno de los curas de la ciudad ${ }^{74}$.

Recíprocamente, los municipios, de manera frecuente, ayudaban a mantener y hacer funcionar hospitales, colegios, obras de beneficencia y cultos o fiestas patronales, sólo por mencionar algunos de los destinos más frecuentes de partidas presupuestarias concejiles. Unas partidas que no era raro que incluyeran la fundación, por ejemplo, de obras pías ${ }^{75}$. Un ejemplo es la dedicación por parte del cabildo de Guanajuato, a principios del siglo XVIII, de parte de las rentas de más de 3.000 pesos anuales obtenidos por el almacenaje de granos en la alhóndiga municipal para el sustento de la labor hospitalaria y educacional de la orden betlehemita. En 1741 ese ayuntamiento aseguraba que podía librar hasta 1.400 pesos anuales para obras de este tipo, lo cual llevó al virrey a aprobar que el consistorio se comprometiera al pago de 200 pesos por año para el mantenimiento del hospital y de la escuela betlehemita ${ }^{76}$. Una circunstancia esta que no evitaba la existencia de conflictos de otra índole entre la propia Iglesia y el concejo, como el éxito que obtuvieron en 1727 algunos eclesiásticos de esa misma villa novohispana al denunciar al responsable de las alhóndigas municipales por cobrarles derechos de almacenaje a pesar de su condición religiosa ${ }^{77}$.

También, como se ha dicho, representaban un monto elevado las cantidades destinadas a celebraciones de días señalados y festivos, tanto de carácter religioso como civil. Pero, incluso en estas últimas, como coronaciones y nacimientos reales, se dedicaban fuertes sumas a actividades litúrgicas, siendo habitual la contratación de misas con una elevada participación de actores, como capellanes, acólitos, cantores y sacristanes, aparte de la compra de cohetes y bombas, la retribución de orquestas musicales, el pago por el toque de las campanas, la celebración de corridas de toros o desfiles de gigantes y cabezudos, sólo por relacionar lo que solía acostumbrarse en poblaciones novohispanas. En cualquier caso, idealmente, cada

\footnotetext{
${ }^{74}$ Licencia y condiciones para que el cabildo de Guanajuato solicite un crédito de 12.000 pesos, otorgada por el virrey de Nueva España, Conde de Fuenclara, México, 5 de marzo de 1743; y Poder especial del cabildo de Guanajuato, 14 de diciembre de 1747. AHUG, PCL, 1747, fs. 257v-266v.Escritura de depósito irregular, Guanajuato, 17 de enero de 1748. AHUG, PCL, 1748, fs. 8v-22v.

75 TERÁN NAJAS, Rosemarie. Censos, capellanías y élites: aspectos sociales del crédito en Quito colonial (primera mitad del s. XVIII). Revista Ecuatoriana de Historia. 1988, n. 1, pp. 23-48; VON WOBESER, Gisela. Las fundaciones piadosas como fuentes de crédito en la época colonial. Historia Mexicana. 1989, n. 4, pp. 779-792.

${ }^{76}$ Autos de remate de propios del cabildo de Guanajuato, 1714. AGN, Bienes Nacionales, 1650, exp. 20; Carta del virrey al cabildo de Guanajuato, 28 de enero de 1741. AGN, Ayuntamientos, 134, exp. 5.

${ }^{77}$ Auto de cabildo, Guanajuato, 10 de julio de 1727. AHUG, Actas de Cabildo, 1721-1732.
} 
uno de esos gastos anotados por el responsable en su libro de cuentas debía acompañarse de un recibo firmado por los cobradores, lo que tampoco estorbaba que dichas partidas y sus destinatarios se realizaran a su arbitrio. Por ejemplo, en 1746 el consistorio guanajuatense consiguió reunir 2.000 pesos para festejar la consecución del título de ciudad obtenido en 1741, un montante que el cabildo confió al procurador para que este decidiera la mejor manera de gastarlo en esos festejos ${ }^{78}$.

No obstante, siguiendo con el ejemplo de dicha ciudad, las poblaciones también recibían instrucciones para moderar esas libranzas, tal y como le ocurrió con motivo de las exequias por la muerte del rey Luis I. Para ellas, el virrey ordenó que se hicieran "moderándose en los gastos, pero sin que falte de nada". Para entender mejor las obligaciones de los responsables de las cuentas municipales, sirva decir que ese "sin que falte de nada" fue suficiente para que el procurador encargado del estipendio presentara su renuncia al cabildo, excusándose en las numerosas obligaciones que tenía en sus haciendas y solicitando la elección de un nuevo individuo para el puesto. Incluso, al dejar el cargo, intentó que se cerrara la cuenta del libro de propios y arbitrios que llevaba hasta ese momento, abriéndose una nueva a partir de la nueva ocupación del cargo por otro, evitando responsabilidades y dejar las cuentas en negativo. El cabildo rechazó la dimisión, obligando al procurador a seguir en el puesto y a hacer frente a los costes de las exequias. Como el propio procurador reconocería más tarde, aceptó seguir en el puesto sólo para que no se le acusara de desacato y a pesar de lo costoso que le resultaría hacerse cargo de los gastos de las honras en honor del monarca fallecido ${ }^{79}$.

\subsection{Otras fuentes de carácter económico}

Finalmente, no queremos terminar sin hacer, aunque sea muy brevemente, referencia a otros tipos documentales que ofrecen información muy útil sobre los propios y arbitrios. Nos referimos a las fuentes generadas por las instituciones y particulares, a veces los mismos cabildos y sus capitulares, responsabilizadas del cobro de impuestos de carácter general, no considerados propiamente municipales, como las alcabalas, diezmos o levas, por ejemplo, así como de la gestión de monopolios y estancos de la Corona, como Correos, el Tabaco, los Naipes, etc., sin olvidar las cuentas de los numerosos oficiales de todos los oficios que, por cualquier motivo, en algún momento proveyeron con sus productos y servicios a los ayuntamientos de las localidades en las que desempeñaban sus trabajos. Unas fuentes que se encuentran dispersas en numerosos archivos a lo largo del mundo hispano, tanto de carácter local, como provincial y estatal, sin olvidar los archivos que resguardan documentaciones específicas de algunas de las instituciones que administraron esos capitales 0 , incluso, de particulares. Todo lo cual haría profuso, y probablemente confuso, intentar relacionar, clasificar o explicar en un breve trabajo

\footnotetext{
${ }^{78}$ Cuentas de la villa y Memoria de los gastos que ejecutó el procurador Manuel González Cedillo, procurador de la villa, por mandado de los señores capitulares, Guanajuato, 1721 y Junta de cabildo, Guanajuato, 30 de junio de 1722. AHUG, Actas de Cabildo, 1721-1732.- Elección de maceros del ayuntamiento, Guanajuato, 20 de junio de 1746. AGN, Ayuntamientos, 134, exp. 5.

79 Juntas de cabildo, Guanajuato, 30 de abril y 2 de mayo de 1725. AHUG, Actas de Cabildo, 1721 1732.
} 
como este, pero que puede identificarse fácilmente en valiosos catálogos documentales realizados en algunos archivos, como el de Sevilla ${ }^{80}$.

De la misma manera, otras instituciones tuvieron evidente contacto con los ayuntamientos, debido a su relación con muchos de los aspectos tratados a lo largo de este trabajo, incluyendo la administración directa de algunos recursos 0 relaciones como prestamistas, arrendatarios, etc. Es el caso de las Diputaciones y Consulados de Comercio, por ejemplo, tal y como se evidencia en la extensa documentación conservada, entre otros repositorios, en el Archivo General de Indias de Sevilla ${ }^{81}$.

\section{Conclusiones}

A modo de conclusión pues, creemos que se hace necesario una revisión completa y sistemática de todas las fuentes expuestas que encontremos a nuestra disposición si se pretende llegar a un conocimiento exhaustivo y a un análisis certero de las cuentas municipales de cualquier ayuntamiento indiano en el intervalo de fecha elegido. Sin una visión de conjunto, sin obtener las distintas perspectivas y asientos contables que cada una de las instituciones y particulares que participaron en ellas, se hace difícil entender la cantidad real de recursos de que disponían, las formas de obtenerlos, de gestionarlos, su destino final y todos los agentes implicados.

\section{Bibliografía}

ABBATE, Georgina. Trayectoria del cabildo en territorios insurgentes. Experiencias políticas en el Río de la Plata (Tucumán, 1809-1824). Temas de historia argentina y americana. 2018, vol. XXVI, pp. 11-38.

ABRIL CASTELLÓ, Vidal. Razón de Estado y política de centro: Diego Pérez de Mesa inventor del "Estado Mesocrático" en la crisis del barroco. Persona y derecho: Revista de fundamentación de las Instituciones Jurídicas y de Derechos Humanos. 1986, n. 15, p. 238.

AGÜERO DÍEZ, María Teresa. El municipio alicantino como agente fiscal de la corona: el equivalente (1759-1788). En: FERNANDEZ ALBADALEJO, Pablo (ed.). Monarquía, Imperio y Pueblos en la España Moderna. Alicante: Universidad de Alicante, 1997, pp. 169-177.

ALBI RODRíGUEZ, María de los Reyes. El Cabildo de Zacatecas como institución política, económica y social (1550-1650) [tesis doctoral]. Universidad de Sevilla, 2015, pp. 428-446.

\footnotetext{
80 SANZ FUENTES, María Josefa y SIMÓ RODRíGUEZ, María Isabel. Catálogo de documentos contenidos en los libros del Cabildo del Concejo de Sevilla. Sevilla: Universidad de Sevilla, 1975 [consultada la segunda edición de 1993].

81 HEREDIA HERRERA, Antonia. Inventario de los fondos de Consulados del Archivo General de Indias. Madrid: Ministerio de Cultura, 1979.
} 
ALBI, Fernando. Derecho municipal comparado del mundo hispánico. Madrid: Aguilar, 1955.

ALTAMIRA Y CREVEA, Rafael. Contribuciones a la Historia Municipal de América. México: Instituto Panamericano de Geografía e Historia, 1951.

ALVA RODRÍGUEZ, Inmaculada. La vida municipal en Manila en los siglos XVI-XVII. Córdoba, universidad de Córdoba, 1997, pp. 133-142.

ANDÚJAR CASTILLO, Francisco; FEROS, Antonio y PONCE LEIVA, Pilar. Corrupción y mecanismos de control en la Monarquía Hispánica: una revisión crítica0 Tiempos Modernos. 2017, vol. 8, n. 35, pp.284-311.

Archivo Histórico de Guayas. Actas del cabildo colonial de Guayaquil. Guayaquil: Archivo Histórico de Guayas, 1972.

Archivo Municipal de Quito. Actas del Cabildo Colonial de San Francisco de Quito. Quito: Archivo Metropolitano de Historia, 1998.

AVELLÁ VIVES, Joaquín. Los cabildos coloniales. Revista de Ciencias Jurídicas y Sociales. 1934, vol. 17, n. 67, pp. 343-374.

AVILA MARTEL, Altamiro. Actividades del Cabildo secular de Santiago en el campo eclesiástico durante el siglo XVI. En: Estructuras, gobierno y agentes de administración en la América española. Valladolid: Instituto de Cooperación Iberoamericana, 1984, pp. 9-42.

BALDIVIEZO, Dionila. El Cabildo de Jujuy, entre el Antiguo Régimen y la República. En: XII Jornadas Interescuelas. Bariloche: Universidad Nacional del Comahue, 2009, pp. 4-5.

BALDIVIEZO, Dionila. Estructura del Cabildo de Jujuy, 1594-1600 [Trabajo de Curso de Postgrado]. Los Cabildos seculares indianos. Una comparativa del poder local en la América española. Universidad Nacional de Salta, julio de 2019, inédito.

BAYLE, Constantino. Los cabildos seculares en la América española. Madrid: Sapientia, 1952.

BELMONTE LÓPEZ, María del Carmen [et al.]. Las actas capitulares como fuente para la historia urbana. En: La ciudad hispánica, siglos XIII al XVI. Madrid: Universidad Complutense, 1987, pp. 39-68.

BERNAL RUIZ, Graciela. Poder local y poder político en el transito del antiguo régimen al estado-nación. San Luis Potosí 1786-1826 [tesis doctoral]. Castellón: Universidad Jaume I, 2009.

BERNARDO ARES, José Manuel de. Presión fiscal y bienes de propios a principios 
del siglo XVII. Axerquía. Revista de estudios cordobeses. 1981, n. 2, pp. 129142.

BERNARDO ARES, José Manuel de. El gobierno del Rey y del Reino. La lucha por el poder desde una perspectiva municipal. En: BERNARDO ARES, José Manuel de y GONZÁLEZ BELTRÁN, Jesús Manuel (coords.). La administración municipal en la Edad Moderna. Cádiz: Universidad de Cádiz; Asociación Española de Historia Moderna, 1999, pp. 26-28, 33-34 y 39.

BERNARDO ARES, José Manuel de. Prólogo. En: POZAS POVEDA, Lázaro. Ciudades castellanas y Monarquía Hispánica. La aportación municipal al gasto del Estado. Córdoba: Universidad de Córdoba, 2001, p. XXI.

BERNARDO ARES, José Manuel de. Corrupción política y centralización administrativa. La hacienda de propios en la Córdoba de Carlos II. Córdoba: Universidad de Córdoba, 1993.

BERTELSEN REPETTO, Raúl. El concepto de Ordenanza en el Derecho emanado de los Cabildos chilenos en el siglo XVII. Justicia, sociedad y economía en la América española. Valladolid: Universidad de Valladolid, 1983, pp. 197-203.

BERTRAND, Michel y MOUTOUKIAS, Zacarías (coords.). Cambio institucional y fiscalidad. Mundo hispánico, 1760-1850. Madrid: Casa Velázquez, 2018.

BERTRAND, Michel. Endeudamiento y poder municipal al fin del periodo colonial: el caso de Puebla. En: BERTRAND, Michel y MOUTOUKIAS, Zacarías. Cambio institucional y fiscalidad. Mundo hispánico, 1760-1850. Madrid: Casa Velázquez, 2018, pp. 141-156.

BLAZQUEZ GARBAJOSA, Adrián. Ensayo de clasificación metodológica de los bienes de propios. En: Actas de las II Jornadas de metodología y didáctica de la Historia. Historia Moderna. Cáceres: Universidad de Extremadura, 1983, pp. 147-157.

BORAH, Woodrow. El gobierno provincial de la Nueva España 1570-1787. México: UNAM, 1985.

BORREGO PLÁ, María del Carmen. Felipe V y Cartagena de Indias: cabildo, crisis y desmembramiento. En: NAVARRO GARCÍA, Luis (coord.). Élites urbanas en Hispanoamérica (De la conquista a la independencia). Sevilla: Universidad de Sevilla, 2005, p. 290.

BUSTAMANTE LÓPEZ, Carlos. Los propios y bienes de comunidad en la provincia de Tlaxcala durante la aplicación de las Reformas Borbónicas, 1787-1804. Estudios de historia novohispana. 2010, n. 43, pp. 145-181.

Cabildo de Caracas. Actas del cabildo de Caracas. Caracas: Tip. Vargas, 1975. 
CAÑO ORTIGOSA, José Luis. Fuentes documentales para el estudio del Cabildo de Guanajuato, 1656-1770. Temas Americanistas. 2009, n. 29, pp. 4-23.

CAÑO ORTIGOSA, José Luis. Las fuentes judiciales para el estudio de los cabildos indianos. Temas Americanistas. 2019, n. 42, pp. 192-213.

CAÑO ORTIGOSA, José Luis. Los cabildos indianos. Estado de la cuestión, fuentes y archivos para un necesario avance historiográfico. REFA. Revista electrónica de fuentes y archivos. 2019, n. 10, pp. 15-37.

CAÑO ORTIGOSA, José Luis. Cabildo y círculos de poder en Guanajuato (16561741). Sevilla: Universidad de Sevilla, 2011.

CAÑO ORTIGOSA, José Luis. El Cabildo de Guanajuato y sus relaciones institucionales (1660-1800). Sevilla: Padilla Libros, 2011.

CAÑO ORTIGOSA, José Luis. Los cabildos en Indias. Un estudio comparado, Corrientes: Moglia Ediciones, 2009.

CARRERA STAMPA, Manuel. Las actas capitulares, fuente de la historia de México. En: ALTAMIRA Y CREVEA, Rafael [et al.]. Contribuciones a la Historia Municipal de América. México: Instituto Panamericano de Geografía e Historia, 1951, p. 135.

CASARIEGO, Jesús Evaristo. El municipio y las Cortes en el imperio español de Indias. Madrid: Talleres Gráficos Marsiega, 1946.

CASTILLO MELÉNDEZ, Francisco. La hacienda municipal indiana: el caso de La Habana y Santiago de Cuba hasta 1700. Anuario de Estudios Americanos. 1985 , n. 42 , pp. 501-547.

CELAYA NÄNDEZ, Yovana. La reforma borbónica en la construcción de la fiscalidad local. Los ayuntamientos novohispanos de Orizaba y Querétaro. En: BERTRAND, Michel y MOUTOUKIAS, Zacarías. Cambio institucional y fiscalidad. Mundo hispánico, 1760-1850. Madrid: Casa Velázquez, 2018, pp. 157-173.

CELAYA NÁNDEZ, Yovana. Las finanzas de las ciudades novohispanas ante el reformismo borbónico: una propuesta historiográfica. En: DUBET, Anne y SOLBES FERRI, Sergio (coords.). La construcción de la Hacienda hispánica en el largo siglo XVIII. Madrid: Casa Velázquez, 2016, pp. 89-97.

CELAYA NÁNDEZ, Yovana. El Ayuntamiento y el Intendente en San Luis Potosí: conflictos y negociación en la administración de los propios y arbitrios, 17681790. Tiempos Modernos. 2016, vol. 33, n. 2, pp. 374-398.

CELAYA NÁNDEZ, Yovana. Administrar y gobernar la hacienda local: contaduría, intendentes y regidores en el siglo XVIII. En: CELAYA NÁNDEZ, Yovana y 
SÁNCHEZ SANTIRÓ, Ernest (coords.). Hacienda e instituciones. Los erarios regio, eclesiástico y municipal en Nueva España: coexistencia e interpelaciones. México: Instituto Mora, 2018, pp. 259-292.

CLAVERO, Bartolomé. Sevilla, Concejo y Audiencia: Invitación a sus ordenanzas de justicia. Ordenanças de la Real Audiencia de Sevilla. Impreso en Sevilla por Bartolomé Gómez, año 1603. Sevilla: Diputación; Universidad; Fundación El Monte, 1995.

Concejo Provincial de Trujillo. Actas del Cabildo de Trujillo. Lima, 1969.

CORONAS GONZÁLEZ, Santos Manuel. Recopilación de Leyes de los Reynos de las Indias. Madrid: Viuda de Joaquín Ibarra, 1791. Quarta Impresión. Edición facsimilar. Madrid: Boletín Oficial del Estado, 1998.

DOMÍNGUEZ COMPANY, Francisco. Estudios sobre las instituciones locales hispanoamericanas. Caracas: Academia Nacional de Historia, 1981.

DOMÍNGUEZ COMPANY, Francisco. Ordenanzas municipales hispanoamericanas. Madrid; Caracas: Asociación Venezolana de Cooperación Intermunicipal; Instituto de Estudios de Administración Local, 1982.

DOMÍNGUEZ COMPAÑY, Francisco. Madrid; Caracas: Asociación Venezolana de Cooperación Intermunicipal, 1982.

ELLIOT, John H. Lengua e Imperio en la España de Felipe IV. Salamanca: Universidad de Salamanca, 1994.

EMMANUELLI, François Xavier. Un Mythe de l'absolutisme bourbonnien: l'intendance, du milieu du XVIle siecle (France, Spagne, Amerique). Aix en Provenze: Universidad de Provenza, 1981.

ENCISO CONTRERAS, José. Zacatecas en el siglo XVI. Derecho y sociedad colonial. Zacatecas: Ayuntamiento de Zacatecas, 2000.

ENSINCK, Óscar Luis. Propios y arbitrios del Cabildo de Buenos Aires, 1580-1821 (Historia económica de una gran ciudad). Madrid: Instituto de Estudios Fiscales, 1990.

ESPANHA, Antonio M. Vísperas del Leviatán Instituciones y poder político, Portugal, siglo XVII. Madrid: Taurus Humanidades, 1989, pp. 41-42.

FIGUEROA QUINTEROS, María Angélica. El Cabildo y el régimen jurídico de la construcción de obra pública en Chile indiano. Notas para su estudio. En: Poder y presión fiscal en la América española (siglos XVI, XVII y XVIII). VI Congreso del Instituto Internacional de Historia del Derecho Indiano. Valladolid: Instituto de Cooperación Iberoamericana, 1986, pp. 403-424. 
FORTEA PÉREZ, José Ignacio. Las ciudades, las Cortes y el problema de representación política en la Castilla Moderna. En: FORTEA PÉREZ, José Ignacio (ed.). Imágenes de la diversidad. El mundo urbano en la Corona de Castilla (s. XVI-XVIII). Santander: Universidad de Cantabria, 1997, pp. 421-446.

GALÁN LORDA, Mercedes. Ordenanzas del Cabildo de México sobre abastos en el siglo XVIII. Anuario de historia del derecho español. 1997, n. 67, pp. 1315-1338.

GALARZA, Antonio Facundo. Las fuentes fiscales del imperio español en América: de las cartas-cuentas a los libros de tesorería. REFA. Revista Electrónica de Fuentes y Archivos. 2019, n. 10, pp. 96-113.

GALARZA, Antonio Facundo. Recaudación fiscal, abasto y control del ganado en el Buenos Aires tardocolonial: los propios y arbitrios del Cabildo entre 1780 y 1820. América Latina en la Historia Económica. 2017, vol. 24, n. 2, pp. 7-34.

GARCÍA GARCÍA, Carmen. Haciendas municipales y bienes de propios: las reformas de Carlos III. Anales de estudios económicos y empresariales. 1986, n. 1, pp. 89-114.

GARCÍA GARCÍA, Carmen. El reformismo borbónico y la fiscalidad local. Quaderni fiorentini per la storia del pensiero giuridico moderno. 1997, vol. 26, n. 1, pp. 5584.

GARCÍA PÉREZ, Rafael. La implantación de las intendencias americanas. reforma y contrarreforma de los propios y arbitrios. En: TORRES AGUILAR, Manuel (coord.). Actas del XV Congreso del Instituto Internacional de Historia del Derecho Indiano. Vol. 2. Córdoba: Diputación Provincial, 2008, pp. 1641-1662.

GARCÍA RUIPÉREZ, Mariano. La administración de las haciendas municipales en la Corona de Castilla en el Antiguo Régimen. Estudio archivístico de sus libros registro. En: La scritura de la memoria: Libros para la administración. Actas de las IX Jornadas de la Sociedad Española de Ciencias y Técnicas Historiográficas. Vitoria, 2012, pp. 41-80.

GARCÍA RUIPÉREZ, Mariano. Fuentes para el estudio de los precios de los alimentos en los archivos municipales españoles en la Edad Moderna: Ios libros del juzgado de fieles ejecutores de Toledo. Cuadernos de Historia Moderna. 2017, vol. 42, n. 1, pp. 261-290.

GARRIGA, Carlos. ¿De qué hablamos cuando hablamos de Derecho Indiano? En: DUVE, Thomas (coord.). Actas del XIX congreso del Instituto Internacional de Historia de Derecho Indiano. Vol. 1. Berlín, 2017, pp. 223-248.

GUILLAMÓN, Francisco Javier y PÉREZ HERVÁS, J. Aproximación al estudio de las haciendas locales bajo Carlos III: Los propios del concejo murciano. Revista de la Facultad de Geografía e Historia. 1989, n. 4, pp. 341-356. 
GUILLOTO, Fernando. Mayordomos de Propios y Arbitrios de la ciudad de Cádiz en el siglo XVIII. Ateneo: Revista cultural del Ateneo de Cádiz. 2009, n. 9, pp. 184187.

GUTIÉRREZ ALONSO, Adriano y MÉNDEZ SÁEZ, Pablo. La hacienda municipal de Burgos en la época moderna. Los bienes de propios (1500-1750). Boletín de la Institución Fernán González. 1997, n. 215, pp. 327-354.

HEREDIA HERRERA, Antonia. La carta como tipo diplomático indiano. Anuario de Estudios Americanos. 1977, vol. XXXIV, pp. 65-95.

HEREDIA HERRERA, Antonia. Inventario de los fondos de Consulados del Archivo General de Indias. Madrid: Ministerio de Cultura, 1979.

HERNANDO SERRA, María Pilar. Un siglo de reformas: Haciendas municipales y reglamentos en la Valencia del XVIII. Anuario de Historia del Derecho Español. 2013, n. LXXXIII, pp. 543-568.

HERRERA MENA, Sajid. El ejercicio de gobernar. Del cabildo borbónico al ayuntamiento liberal. El Salvador colonial, 1750-1821. Castellón: Universidad Jaume I, 2013.

HIJANO PÉREZ, Ángeles. El pequeño poder. El municipio en la Corona de Castilla: siglos XV al XIX. Madrid: Fundamentos, 1992.

HOYO, Eugenio del. Primer Libro de Actas de Cabildo de las minas de Zacatecas, 1557-1586. Zacatecas: Edición del Ayuntamiento, 1990.

INGRAM PRIESTLEY, Herbert. Municipalidades coloniales españolas. México: Hermanos Porrúa, 1921.

JIMÉNEZ JIMÉNEZ, Ismael. Una herramienta inútil. Juicios de residencia y visitas en la Audiencia de Lima a finales del siglo XVII. Temas Americanistas. 2015, n. 35, pp. 60- 87.

KINSBRUNER, Jay. The Colonial Spanish-American City. Urban Life in the Age of Atlantic Capitalism. Austin: University of Texas Press, 2005.

LAVIANA CUETOS, María Luisa. Las Ordenanzas municipales de Guayaquil, 1590. Anuario de Estudios Americanos. 1983, vol. XL, pp. 39-69.

LAVRIN, Asunción y BAUER, Arnold Bauer. La Iglesia en la economía de América Latina Siglos XVI al XIX. México: Instituto Nacional de Antropología e Historia, 1986.

LOHMANN VILLENA, Guillermo. Las ordenanzas municipales de Lima (1533-1635). Separata del III Congreso del Instituto Internacional de Historia del Derecho Indiano. Madrid: Instituto Nacional de Estudios Jurídicos, 1973. 
LÓPEZ DÍAZ, María. Señorío y municipalidad. Concurrencia y conflicto de poderes en la ciudad de Santiago (siglos XVI y XVII). Santiago de Compostela: Universidad de Santiago, 1997, pp. 39-41.

LORENTE TOLEDO, Luis. Los 'propios y arbitrios' municipales. Una opción para el análisis social en la realidad económica del siglo XIX. En: CASTILLO, Santiago. La historia social en España: actualidad y perspectivas: Actas del I Congreso de la Asociación de Historia Social. Zaragoza: Siglo XXI, 1991, pp. 337-344.

LUCENA GIRALDO, Manuel. A los cuatro vientos. Las ciudades de la América Hispánica. Madrid: Fundación Carolina; Centro de Estudios Hispánicos e Iberoamericanos, Marcial Pons, 2006.

MACHUCA, Laura (coord.). Ayuntamientos y sociedad en el tránsito de la época colonial al siglo XIX. Nueva España y Centroamérica. México: CIESAS, 2014.

MÁLAGA MEDINA, Alejandro. Índice del libro segundo de Actas de Sesiones y Acuerdos del Cabildo de la Ciudad de Arequipa 1546-1556. Arequipa: el Sol, 1974.

MALAGÓN PINZÓN, Miguel. Las visitas indianas, una forma de control de la administración pública en el estado absolutista. Vniversitas. 2004, n. 108, pp. 821-838.

MARCHIONNI, Marcelo Daniel. Política y sociedad en Salta y el norte argentino, 1780-1850. Salta: ICSOH/UEUCASA, 2019.

MARICHAL, Carlos. La Iglesia y la crisis financiera del virreinato, 1780-1808: apuntes sobre un tema viejo y nuevo. Revista Relaciones de Historia y Sociedad. 1989, n. 40, pp. 103-129.

MARILUZ URQUIJO, José María. El municipio indiano en el siglo XVIII. Revista de Estudios Histórico-Jurídicos. 2006, n. 28, pp. 157-174.

MARILUZ URQUIJO, José María. Ensayo sobre los juicios de residencia indianos. Sevilla: Escuela de Estudios Hispanoamericanos, 1952.

MARTÍNEZ LÓPEZ-CANO, María del Pilar. La Iglesia y el crédito en Nueva España: entre viejos presupuestos y nuevos retos de investigación. En: MARTíNEZ LÓPEZ-CANO, M. (coord.). La Iglesia en Nueva España. Problemas y perspectivas de investigación. México: Universidad Nacional Autónoma de México; Instituto de Investigaciones Históricas, 2010, pp. 303-352.

MARTÍNEZ NEIRA, Manuel. El municipio controlado. Los reglamentos de propios y arbitrios en las reformas carolinas. América Latina en la Historia Económica. 1997, vol. 4, n. 7, pp. 9-17.

MARULANDA RESTREPO, Juan Sebastián. Instituciones eclesiásticas y crédito en 
Antioquia, siglo XVIII. Revista Historia y Sociedad. 2016, n. 31, pp. 171-203.

MATEOS ROYO, José Antonio. Propios, arbitrios y comunales: la hacienda municipal en el Reino de Aragón durante los siglos XVI y XVII. Journal of Iberian and Latin American Economic History. 2003, año 21, n. 1, pp. 51-78.

MATHERS, Constance Jones. Relations between the City of Burgos and the Crown, 1506-1556. Columbia University, 1973.

MERINO, Luis. El cabildo secular: aspectos fundacionales y administrativos. Estudio sobre el municipio. Manila: Intramuros Administration, 1983.

MERINO, Luis. Política de doblamiento de España en América. La fundación de ciudades. Madrid: Instituto de Estudios de Administración Local, 1984.

MOLINA ARGÜELLO, Carlos. Las visitas-residencias y residencias-visitas de la Recopilación de Indias. Caracas: Academia Nacional de la Historia, 1975.

MOLINA MARTÍNEZ, Miguel. El municipio en América. Aproximación a su desarrollo histórico. Granada: CEMCI, 1996.

MORENO AMADOR, Carlos. El valor del Juicio de Residencia como fuente documental: estructura, características y peculiaridades. El paradigma de Tabasco en la segunda mitad del siglo XVIII. En: CAÑO ORTIGOSA, José Luis y VASSALLO, Jaqueline (coords.). "Dossier Las fuentes judiciales en el Americanismo: Instituciones, archivos, sujetos y desafíos metodológicos". Temas Americanistas. 2019, n. 42, pp. 160-191.

MORENO AMADOR, Carlos. Gobernar bajo sospecha. Estrategias del poder y prácticas corruptas en la Alcaldía Mayor de Tabasco (1660-1716). Sevilla: Universidad de Sevilla, 2018, pp. 113-137 y 184-196.

MURO OREJÓN, Antonio. Reformas e innovaciones en los municipios hispanoindianos en el siglo XVIII. En: Actas VI Congreso Internacional de Historia de América. Tomo III. Buenos Aires: Academia Nacional de la Historia, 1982, pp. 259-275.

NADER, Helen. Liberty in Absolutist Spain. The Habsburg Sale of Towns, 1516-1700. Baltimore: The John Hopkins University Press, 1990.

NúÑEZ ROLDÁN, Francisco. Haciendas municipales en el Reino de Sevilla a mediados del siglo XVIII. Historia. Instituciones. Documentos. 1985, n. 12, pp. 89-90.

OROZCO Y BERRA, Manuel. Actas de Cabildo de la Ciudad de México. México: Aguilar e Hijos, 1889-1911.

OTERO D'COSTA, Enrique (comp.). Primer libro de actas del cabildo de la ciudad de 
Pamplona en la Nueva Granada, 1552-1561. Bogotá: Academia de la Historia, 1950.

OTS CAPDEQUÍ, José María. El régimen municipal hispanoamericano del período colonial, concejos y ciudades. Tierra Firme. 1937, n. 3 y 4, pp. 353-381.

OTS CAPDEQUÍ, José María. El municipio hispanoamericano en la época colonial. Anuario de Historia del Derecho Español. 1924, pp. 93-147.

OTS CAPDEQUÍ, José María. El Estado español en Indias. México: Fondo de Cultura Económica, 1993.

PARRILLA ALBUERNE, Ana María. Propios y arbitrios del ayuntamiento de Ciudad Real. Un pulso entre el poder local y los nuevos funcionarios de la intendencia, 1786-1812. En: ORTIZ HERRERA, María del Rocío (coord.). Ayuntamientos chiapanecos: fiscalidad, elecciones, ciudadanía y defensa de bienes de comunidad desde la Colonia hasta el inicio de la Revolución en Chiapas. México: El Colegio de Michoacán, 2018, pp. 17-48.

PAYNE IGLESIAS, Elizeth. Poderes locales y resistencia popular en Nicaragua, 1808-1813. En: POLLACK, Aaron. La época de las independencias en Centroamérica y Chiapas. México: Instituto Mora, 2013, pp. 123-158.

PAZ, Gustavo L. y SICA, Gabriela. La frontera oriental del Tucumán en el Río de la Plata (siglos XVI-XVIII). En: TRUCHUELO, Susana. Las fronteras en el mundo atlántico: (Siglos XVI-XIX). La Plata: Universidad Nacional de La Plata, 2017, pp. 301-305.

PAZOS PAZOS, María Luisa Julia. Guía de las actas de cabildo de la ciudad de México 1766-1775. México: Universidad Iberoamericana, 1981.

PÉREZ DE MESA, Diego. Política o Razón de Estado. Edición crítica de PEREFLA, Luciano [et al.]. Madrid: CSIC, 1980, pp. 262-266.

PEZZI CRISTÓBAL, Pilar y VILLAS TINOCO, Siro. Poder y contrapoder: las reformas municipales de Carlos III en Andalucía Oriental. En: ALVAR, Alfredo [et al.]. Política y cultura en la Edad Moderna. Madrid: Universidad de Alcalá, 2004, pp. 803-809.

PEZZI CRISTÓBAL, Pilar. Intervencionismo regio en los Cabildos Municipales del Setecientos: el caso de Vélez-Málaga. En: Seminário monarquias ibéricas e elites locais no período moderno [en línea]. Universidade de Lisboa, Faculdade de Letras, 6 Outubro $2015 . \quad$ Disponible en $<$ https://riuma.uma.es/xmlui/handle/10630/10515>.

PIERSON, William W. Some reflections on the Cabildo as an institution. Hispanic American Historical Review. 1922, vol. V, n. 4, pp. 573-596. 
PIKE, Frederick B. The cabildo and colonial loyalty to Hapsburg Rulers. Journal of Interamerican Studies. 1960, vol. II, n. 4, 1960, pp. 405-420.

POZAS POVEDA, Lázaro. Ciudades castellanas y Monarquía Hispánica. La aportación municipal al gasto del Estado. Córdoba: Universidad de Córdoba, 2001.

RAHN PHILLIPS, Carla. Las ordenanzas del ayuntamiento de Ciudad Real en 1632: retrato de una ciudad en las llanuras. Chronica Nova. 1989, n. 17, pp. 417-439.

RAMOS PÉREZ, Demetrio. Los cabildos señoriales de la época de Diego Colón. Buenos Aires: Instituto de Investigaciones de Historia del Derecho, 1977.

REAL DÍAZ, José Joaquín. Catálogo de las cartas y peticiones del cabildo de San Juan Bautista de Puerto Rico en el Archivo General de Indias (siglo XVI-XVIII). Barcelona: Instituto de Cultura puertorriqueña, 1968.

REYES OCHOA, Rodolfo. El municipio en la vida americana. México: S.P.I., 1902.

RODRÍGUEZ MOREL, Genaro. Cartas de cabildo de la ciudad de Santo Domingo en el siglo XVI. Santo Domingo: Patronato de la ciudad colonial de Santo Domingo, 1999.

ROMERO DE SOLÍS, José Miguel. Conquistas e instituciones de gobierno en Colima de la Nueva España (1523-1600). México: El Colegio de Michoacán, 2007, p. 310.

RUBÍN CÓRDOBA, Fernando. La intervención del Asistente e Intendente de Sevilla en la administración de las rentas municipales y provinciales. En: $X V$ Congreso AECA [en línea]. Valladolid, septiembre de 2009. Disponible en $<$ http://www.aeca1.org/pub/on line/comunicaciones xvcongresoaeca/cd/60e.pdf $>$.

RUBÍN CÓRDOBA, Fernando. La Institución de la Contaduría General y Propios y Arbitrios del Reino: organización y normalización de las cuentas (1760-1764). En: VII Encuentro de Trabajo Historia de la Contabilidad [en línea]. León, 12 de noviembre de 2010. Disponible en $<$ https://www.aeca.es/old/vii encuentro trabajo historia contabilidad/pdf/13 Ru bin Cordoba.pdf>.

SALAMANCA LÓPEZ, Manuel Joaquín. Organización de la Hacienda madrileña durante el reinado de Fernando VI: las contadurías. Cuadernos de investigación histórica. 2015, n. 32, pp. 89-120.

SALGADO, José. Los cabildos coloniales. Montevideo, 1910.

SÁNCHEZ BELLA, Ismael. Visitas a Indias (siglos XVIXVII).en: Derecho indiano: estudios. Pamplona, EUNSA, 1991. 
SÁNCHEZ BELLA, Ismael. Visitas a la Audiencia de. México (siglos XVI y XVII). Anuario de Estudios Americanos. 1975, n. 32, pp. 375-402.

SÁNCHEZ BELLA, Ismael. La organización financiera de las Indias, siglo XVI. Sevilla: Escuela de Estudios Hispanoamericanos, 1968, pp. 318-325.

SÁNCHEZ BELLA, Ismael. El Juicio de Visita en Indias. En: IV Congreso del Instituto Internacional de Historia del Derecho Indiano. México: IIHDI, 1976, pp. 579-626.

SANTAYANA Y BUSTILLO, Lorenzo de. Gobierno político de los pueblos de España y el corregidor, alcalde y juez de ellos. Edición de TOMÁS Y VALIENTE, Francisco. Madrid: Instituto de Estudios de Administración Local, 1979.

SANTOS PÉREZ, José Manuel. Élites, poder local y régimen colonial: El Cabildo y los regidores de Santiago de Guatemala 1700-1787. Cádiz: Universidad de Cádiz, 1999, p. 118.

SANZ FUENTES, María Josefa y SIMÓ RODRÍGUEZ, María Isabel. Catálogo de documentos contenidos en los libros del Cabildo del Concejo de Sevilla. Sevilla: Universidad de Sevilla, 1975 [consultada la segunda edición de 1993].

SILVA RIQUER, Jorge. La reforma fiscal de los ayuntamientos novohispanos (17651812). Madrid: Marcial Pons, 2015.

SOLANO PÉREZ, Francisco de. Historia y futuro de la ciudad iberoamericana. Madrid: Centro de Estudios Históricos, 1986.

SUÁREZ GRIMÓN, Vicente J. La reforma de la hacienda municipal en Canarias en el siglo XVIII: el conflicto en torno al establecimiento de la contaduría de propios y arbitrios. Las Palmas de Gran Canaria: Cabildo de Gran Canaria, 2005.

TANCK DE ESTRADA, Dorothy. Pueblos de indios y educación en el México colonial, 1750-1821. México: El Colegio de México, 1999, pp. 17-75.

TAPIA, Francisco Xavier. El cabildo abierto colonial. Madrid: Cultura Hispánica, 1966.

TAU ANZOATEGUI, Víctor. El Derecho municipal del Perú. Apuntes sobre su configuración. En: La Ley en América Hispánica. Buenos Aires: Academia Nacional de la Historia 1992, pp. 313-345.

TAU ANZOÁTEGUI, Víctor, Nuevos horizontes en el estudio histórico del Derecho Indiano. En: INHIDE (XI Congreso del Instituto Internacional de Historia del Derecho Indiano). Buenos Aires, 1997.

TERÁN NAJAS, Rosemarie. Censos, capellanías y élites: aspectos sociales del crédito en Quito colonial (primera mitad del s. XVIII). Revista Ecuatoriana de Historia. 1988, n. 1, pp. 23-48. 
VALIENTE OTS, Mauricio. El tratamiento de los no-españoles en las ordenanzas municipales indianas. Estudios de historia social y económica de América. 1996, n. 13, pp. 47-51.

VERGARA, Miguel Ángel. Orígenes de Jujuy (1535-1600). Salta: Talleres Gráficos "San Martín", 1961.

VILA VILAR, Enriqueta; JAVIER ORTIZ DE LA TABLA, Javier y TORRES RAMÍREZ, Bibiano. Cartas de cabildos hispanoamericanos: Audiencia de Guatemala. Sevilla: Escuela de Estudios Hispanoamericanos, 1984.

VILA VILAR, Enriqueta, y SARABIA VIEJO, María Justina. Cartas de cabildos hispanoamericanos. Audiencia de México. Sevilla: Escuela de Estudios Hispanoamericanos, 1985.

VON WOBESER, Gisela. El crédito eclesiástico en la Nueva España, siglo XVIII. Revista América Latina en la Historia Económica. 1994, n. 6, pp. 9-19.

VON WOBESER, Gisela. Las fundaciones piadosas como fuentes de crédito en la época colonial. Historia Mexicana. 1989, n. 4, pp. 779-792.

VON WOBESER, Gisela. Mecanismos crediticios en la Nueva España el uso del censo consignativo. Estudios mexicanos. 1989, n. 1, pp. 1-23.

WOLFF, Inge. Der cabildo im kolonialen Spanisch-Amerika. Jahrbuch für Geschichte von Staat, Wirtschaft und Gesellschaft Lateinamerikas. 1964, vol. I, pp. 365-371.

ZABALA MANTARAS, Olga. Cabildos coloniales. Montevideo, 1953.

ZABALZA SEGUIN, Ana. Las ordenanzas locales como fuente para el estudio de la demografía navarra. En: NADAL OLLER, Jordi (coord.). La evolución demográfica bajo los Austrias. Alicante: Instituto de Cultura Juan Gil-Albert, 1991, pp. 127-133.

ZORRAQUÍN BECÚ, Ricardo. El sistema de fuentes en el Derecho indiano. Anuario Histórico-jurídico ecuatoriano. 1980, vol. VI, pp. 3-54.

ZUMALACARREGUI, Leopoldo. Visitas y residencias en el siglo XVI. Unos textos para su distinción. Revista de Indias. 1946, n. 26, pp. 917-921. 